\title{
EDUCAÇÃO AMBIENTAL E POLÍTICA PÚBLICA EDUCACIONAL: UMA ABORDAGEM INTERDISCIPLINAR NA PERSPECTIVA DA INTERVENÇÃO SOCIAL A PARTIR DO PROJETO OCUPE A PRAÇA (SÃO PAULO-SP)
}

\author{
Maria Cristina dos Santos Pereira ${ }^{1}$ \\ Luciana Aparecida Farias ${ }^{2}$ \\ Zysman Neiman ${ }^{3}$
}

Resumo: A Educação Ambiental (EA) desperta, entre vários atores sociais, a discussão sobre quem são os responsáveis pelos cuidados com o meio ambiente. Nesse sentido muitas escolas realizam atividades nessa área e tentam construir, junto com seus educandos, conceitos a respeito das responsabilidades com o entorno socioambiental que, por vezes, se refletem em ações positivas para a natureza. Dentro dessa perspectiva uma escola municipal do ensino fundamental do município de São Paulo promove várias atividades pedagógicas, dentre elas o Projeto Ocupe a Praça, uma intervenção social realizada em num espaço localizado em frente à escola. $O$ objetivo da presente pesquisa, a partir do projeto Ocupe a Praça, foi avaliar se a política pública educacional adotada no município de São Paulo, por meio da proposta Currículo da Cidade, favorece a corrente de Educação Ambiental Crítica. Para tanto, foi realizado um estudo de caso, com coleta de dados mediante questionários mistos, sugerindo as representações sociais dos diferentes atores a respeito de meio ambiente e de EA, a análise documental do Currículo da Cidade, do Projeto Ocupe a Praça e dos Projetos Político-Pedagógicos da unidade escolar, entre os anos de 2012 a 2017. Os resultados foram tratados conforme a análise de conteúdo com a triangulação de dados e a classificação das representações sociais. Os resultados obtidos apontaram uma visão globalizante sobre o meio ambiente e EA. Indicaram também que o Currículo da Cidade não está apoiando uma Educação Ambiental Crítica. No entanto, esta corrente pode estar presente nos espaços escolares se, em seus projetos político-pedagógicos, estiverem contemplados debates e práticas interdisciplinares. São escolas construindo seus próprios currículos com uma abordagem da Educação Ambiental Crítica.

Palavras-chave: Currículo; Educação Ambiental Crítica; Escola Pública; Ensino Fundamental; Interdisciplinaridade

1 Universidade Federal de São Paulo, Diadema, SP. E-mail: mcristinasp@uol.com.br.

2 Universidade Federal de São Paulo, Diadema, SP. E-mail: lufarias2@yahoo.com.br

3 Universidade Federal de São Paulo, Diadema, SP. E-mail: E-mail: zneiman@gmail.com. 
Abstract: Environmental Education (EE) arouses, among various social actors, the discussion about who is responsible for caring for the environment. In this sense, many schools carry out activities in this area and try to build, along with their students, concepts about the responsibilities with the social and environmental environment that sometimes are reflected in positive actions for nature. Within this perspective, a municipal elementary school in the city of São Paulo promotes various pedagogical activities, including the Ocupe a Praça Project, a social intervention held in a space located in front of the school. The objective of the present research, based on the Ocupe a Praça project, was to evaluate whether the educational public policy adopted in the city of São Paulo, through the proposed City Curriculum, favors the Critical Environmental Education chain. Therefore, a case study was conducted, with data collection through mixed questionnaires, suggesting the social representations of the different actors regarding the environment and EE, the documentary analysis of the City Curriculum, the Ocupe a Praça Project and the political-pedagogical projects of the school, from 2012 to 2017 . The results were treated according to content analysis with data triangulation and classification of social representations. The obtained results pointed to a globalizing vision about the environment and EE. They also indicated that the City Curriculum has not supporting Critical Environmental Education. However, this current may be present in school spaces if, in their political-pedagogical projects, interdisciplinary debates and practices are contemplated. They are schools building their own curriculum with a Critical Environmental Education approach.

Key words: Curriculum; Critical Environmental Education; Public school; Elementary School; Interdisciplinarity

\section{Introdução}

Perceber o meio ambiente, ainda que tenhamos consciência disso ou não, é muito mais que simplesmente uma sensação que recebemos passivamente quando recebemos estímulos por meio dos nossos sentidos físicos. Uma percepção ambiental, segundo Ferrara (1999), gera conhecimento a partir das informações retidas e codificadas nos usos e hábitos, signos do lugar, diminuindo a opacidade do meio.

Pode ainda, se devidamente trabalhada ao longo da nossa trajetória formativa, influenciar o modo de como o ser humano trata as questões ambientais, desenvolvendo o "amor ao lugar", a Topofilia (TUAN, 2012) que é sentida por meio da percepção, das atitudes, dos valores e da visão de mundo que são constituídos cultural e socialmente.

Neste sentido, a escola e os professores exercem um papel fundamental no estímulo da percepção ambiental, desenvolvendo habilidades dos discentes, proporcionando uma compreensão crítica e incentivando a participação nos debates das questões ambientais com uma abordagem holística, incluindo questões ecológicas, sociais, culturais, políticas, históricas e éticas, dentre outras (FARIAS et al., 2017).

Os educadores ambientais têm a responsabilidade de contribuir com a melhoria das condições de vida das comunidades e colaborar com um diálogo 
permanente, tentando superar-se como agentes transformadores da sociedade (OTERO; NEIMAN, 2015).

Segundo Santana, Romero e Farias (2019, p.15) atividades pedagógicas em Educação Ambiental possibilitam "desenvolver a percepção ambiental e uma reflexão mais crítica em relação a realidade socioambiental onde a atividade é desenvolvida". E se as atividades forem realizadas em praças pode-se estimular além do contato físico do ser humano com elementos da natureza, trazendo a possibilidade de despertar a preservação cultural, ambiental e afetiva.

Atividades em praças levam ao ativismo ambiental e buscam a melhoria do entorno, da qualidade de vida e do despertar para o envolvimento das pessoas nos debates. O ativista ambiental atua no local em que se está inserido, percebendo quando algo está em desacordo, transformando-o, levando os benefícios à vida de todos (BAEDER et al., 2000).

Portanto, desenvolver projetos de Educação Ambiental (EA) na praça pode ser bastante interessante para se proporcionar o debate crítico em relação às questões socioambientais. Favorece ainda 0 sentimento de pertencimento neste espaço, às vezes não percebido pelas pessoas, que passam a frequentá-lo gerando novas relações e novos sentidos (TUAN, 2012).

Ferrara (1999) traz a concepção de que a praça é um espaço no qual todos são atores e espectadores ao mesmo tempo. Ủm local urbano povoado de marcas, sinais com imagens próprias da cidade, um espaço livre e público, pois a praça rompe a barreira da vida privada, das normas familiares, da hierarquia social, e faz o privado se tornar público e o individual se coletivizar.

Diante do exposto realizou-se um estudo de caso em uma escola municipal de ensino fundamental, localizada na zona oeste de São Paulo, que construiu e implementou um projeto em Educação Ambiental, o Projeto Ocupe a Praça (POP) - Trabalho Colaborativo de Autoria (TCA) - elaborado em atendimento à politica pública educacional do Município de São Paulo no período de 2013 a 2016 - o Programa Mais Educação São Paulo (SÃO PAULO, 2014a).

O POP desenvolveu várias atividades realizadas em uma praça localizada em frente à escola e vem mostrando resultados promissores com relação à uma prática de EA com concepção crítica e no desenvolvimento de sentimentos topofílicos. Contudo, as pessoas não percebem ou representam o meio ambiente da mesma forma (REIGOTA, 2007), por isso julgou-se importante, no presente estudo, também avaliar quais são as representações e sentidos atribuídos ao Meio Ambiente e Educação Ambiental entre os diferentes atores desta comunidade escolar.

Buscou-se entender as contribuições do POP dentro de uma perspectiva de Educação Ambiental Crítica, bem como, a Representação Social do corpo docente e discente sobre o meio ambiente, a presença da EA nos planos de ensino, no Projeto Político Pedagógico e no Currículo da Cidade, partindo-se 
da seguinte questão: a Educação Ambiental Crítica está contemplada no currículo do município de São Paulo?

A pesquisa utilizou como apoio os principais referenciais teóricos das Representações Sociais de Moscovici (1978) e Reigota (2007), da Topofilia de Tuan (2012), das macrotendências de Educação Ambiental no Brasil segundo Layrargues e Lima (2014) e da pedagogia de Freire (1996).

\section{O Projeto Ocupe a Praça e sua localização}

O projeto Ocupe a Praça, um Trabalho Colaborativo de Autoria (TCA) com intervenção social, foi desenvolvido por uma escola Municipal de São Paulo em resposta à política pública educacional Mais Educação São Paulo (SÃO PAULO, 2014a), tendo início no ano de 2014.

Durante a elaboração do TCA, por meio de debates e diálogos com a comunidade escolar, surgiram várias sugestões de temas para serem desenvolvidos pelos estudantes e o tema em destaque foi a necessidade de se realizar uma intervenção na Praça Dr. José Ória, particularmente por ser um local que reúne estudantes antes e depois do horário escolar, um ponto de encontro e passagem de um número significativo de transeuntes.

Concluiu-se, então, que a praça deveria ser melhor cuidada, pois até aquele momento era um espaço público abandonado, servindo como depósito de rejeitos, foco de doenças e de vulnerabilidade social, onde havia frequentemente a ocorrência de pequenos furtos, sequestros relâmpagos, agressões físicas, roubos de carros e outras formas de violências. Isso fazia com que os transeuntes dessem a volta no quarteirão, evitando passar pela praça, mesmo sendo um ótimo atalho para acessar o ponto de transporte público. Isso acontecia também com os estudantes ao acessar a escola.

Primeiramente, os discentes fizeram um diagnóstico sobre as necessidades para a revitalização da praça e, coletivamente, foram construindo o planejamento e as estratégias de ações para desenvolver o POP. De modo interdisciplinar as disciplinas do ensino fundamental - língua portuguesa, língua inglesa, ciências, matemática, história, geografia, arte e educação física traçaram, junto com seus estudantes, procedimentos que pudessem trazer a revitalização deste espaço.

As áreas que entraram na intervenção foram: a Praça Dr. José Ória, contornada pelas Ruas Joaquim Galvão e Grauçá e ao lado da praça, a Escola Municipal Des. Theodomiro Dias (Figura 1). Ambas fazem parte do distrito Vila Sônia, subprefeitura do Butantã, município de São Paulo, Capital. 


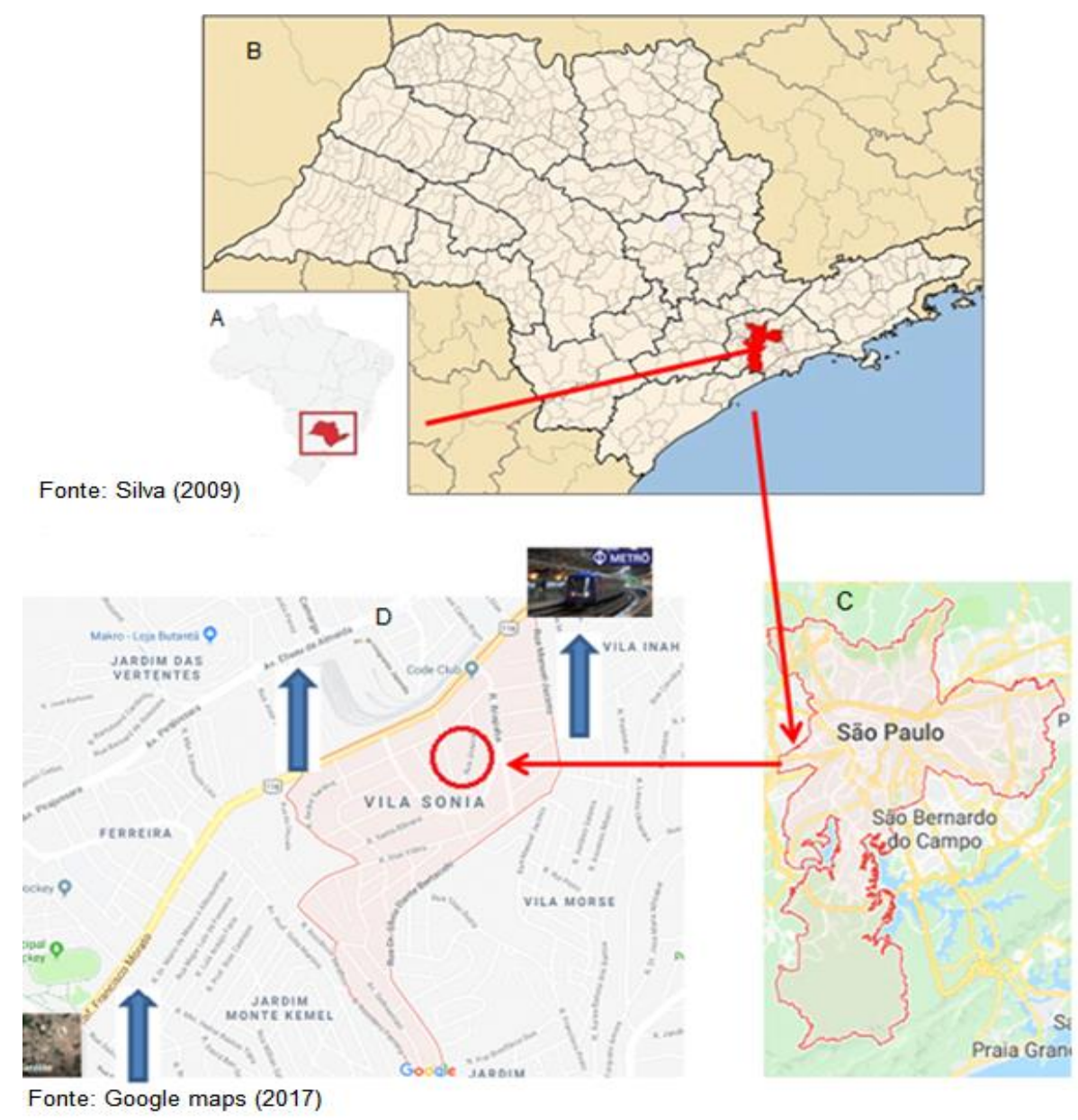

Figura 1: Localização geográfica das áreas de estudo: a) Brasil. b) Estado de São Paulo - $23^{\circ}$

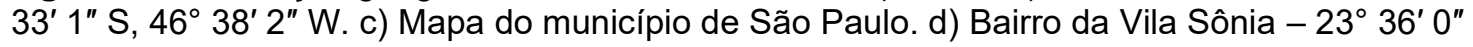
S, $46^{\circ} 44^{\prime} 35^{\prime \prime}$ W.

Segundo o IBGE (2010), o distrito Vila Sônia tem uma economia que gira em torno da prestação de serviços, comércios e indústrias. É considerada uma região de classe média, população e Índice de Desenvolvimento Humano elevados (IDH: 0,895). Entretanto, observam-se casas e vilarejos antigos, com moradores que vivem em condições precárias (SÃO PAULO, 2007b). Entre o período dos anos 2000 e 2010 houve um aumento na população (de 87.379 para 108.441 habitantes) e na densidade populacional (de 8.826 para 10.954 $\mathrm{hab} / \mathrm{km}^{2}$ ) (IBGE, 2010), ocupando assim o segundo lugar como distrito mais populoso da Subprefeitura Butantã, que conta com um total de 428.217 hab.

Recentemente, esse distrito sofreu drásticas mudanças nas proximidades da Praça Dr. José Ória devido às obras da linha amarela do metrô, empreendimentos imobiliários e comércios de diversos segmentos. Portanto, por ser uma área fortemente urbanizada existe um alto fluxo de pessoas e veículos, aumentando o impacto nos espaços públicos e nas áreas verdes. Devido à grande circulação de pessoas na praça é comum se encontrar resíduos de variados tipos, indicando o desprezo, o desrespeito e a falta de 
amor com o espaço público, apontando um baixo sentimento topofílico com o entorno (TUAN, 2012).

A Praça Dr. José Ória, com seus $15.100 \mathrm{~m}^{2}$ de área (Figura 2), é a maior área verde localizada no centro do distrito e trata-se de um espaço rodeado por muitas casas e poucos prédios.

A praça contém biodiversidade vegetal e animal, três pequenos lagos com nascentes, palco para eventos, alguns bancos para descanso, uma quadra poliesportiva, mesas de xadrez e aparelhos de ginástica, evidenciando a importância de se resgatar o sentimento topofílico em relação a este lugar entre os moradores e frequentadores da região. As praças são espaços públicos de lazer que podem favorecer a integração e a socialização da população, da mesma forma que podem resgatar o sentimento comunitário. São espaços dotados de símbolos, sejam imaginários ou reais e quando bem cuidados podem despertar o sentimento de hospitalidade pública.

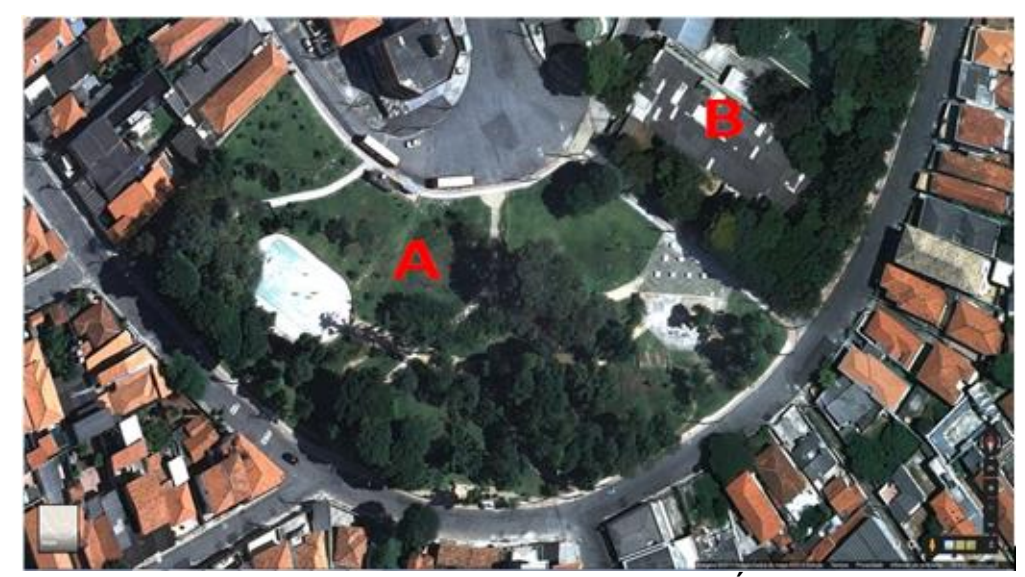

Figura 2: Fotografia aérea, em destaque a Praça Dr. José Ória - Vila Sônia, Butantã (São Paulo, SP) (A) e a Escola Municipal do Ensino Fundamental participante do estudo (B).

Fonte: Google Maps

\section{Percurso Metodológico}

Esta pesquisa teve caráter qualitativo cuja estratégia de investigação utilizada foi um estudo de caso exploratório, um método específico, que permitiu explorar profundamente o POP e seus registros, documentos que embasaram sua elaboração, implantação e seus resultados.

Segundo Yin (2010), os elementos básicos para um estudo de caso são: enfoque contemporâneo da realidade, pouco controle sobre o fenômeno estudado e questionamento sobre o como e o porquê, com respostas podendo vir de fontes distintas. Também é caracterizado como um estudo do contexto social e suas interconexões, com subjetividade da busca, com conhecimento científico, partindo da observação direta do pesquisador, e é exploratório quando não possui um único e claro conjunto de resultados.

A investigação foi conduzida por três componentes estruturantes: a concepção filosófica, estratégias de investigação e o método específico da 
pesquisa. A concepção filosófica do construtivismo social defende 0 entendimento do mundo em que os indivíduos vivem e trabalham (CRESWELL, 2010).

E método específico de pesquisa, o método misto, foi utilizada uma abordagem que combina ou associa o modo qualitativo e o quantitativo, coletando e integrando as duas formas para obter informações e interpretar os resultados (CRESWELL, 2010). Para indicar a consistência metodológica que foram realizadas, segue a matriz de amarração dos elementos estruturantes dessa pesquisa está destacada no Quadro 1 (MAZZON, 1981).

Quadro 1: Matriz de amarração dos elementos estruturantes da pesquisa.

\begin{tabular}{|c|c|c|c|c|}
\hline \multicolumn{5}{|c|}{$\begin{array}{l}\text { Pergunta da Pesquisa: A política pública educacional, representada pelo currículo adotado no município de } \\
\text { São Paulo, subsidia a corrente de EA crítica? }\end{array}$} \\
\hline \multicolumn{5}{|c|}{$\begin{array}{c}\text { Objetivo Principal: Avaliar se a política pública educacional representada pelo currículo adotado no município } \\
\text { de São Paulo subsidia a corrente de EA crítica, a partir da experiência do POP. }\end{array}$} \\
\hline Objetivos específicos & $\begin{array}{l}\text { Questões } \\
\text { direcionadoras }\end{array}$ & Fonte & $\begin{array}{l}\text { Técnica de coleta } \\
\text { de dados }\end{array}$ & Técnica de análise de dados \\
\hline $\begin{array}{l}\text { 1. Investigar as } \\
\text { percepções dos } \\
\text { docentes e discentes } \\
\text { sobre o meio } \\
\text { ambiente. }\end{array}$ & $\begin{array}{c}\text { Qual é o perfil } \\
\text { dos docentes e } \\
\text { dos discentes em } \\
\text { relação ao que é } \\
\text { meio ambiente? }\end{array}$ & $\begin{array}{c}\text { Atividades } \\
\text { realizadas pelos } \\
\text { docentes e } \\
\text { discentes. }\end{array}$ & $\begin{array}{l}\text { Desenhos sobre } \\
\text { o meio ambiente. }\end{array}$ & \multirow{2}{*}{$\begin{array}{c}\text { Análise dos } \\
\text { macrocompartimentos e } \\
\text { macroelementos (PEDRINI; } \\
\text { COSTA; GHILARDI, 2010). } \\
\text { RS sobre meio ambiente: } \\
\text { globalizante, naturalista e } \\
\text { antropocêntrico (REIGOTA, } \\
\text { 2007). } \\
\text { Abordagens } \\
\text { conservacionista, } \\
\text { pragmática e crítica } \\
\text { (LAYRARGUES e LIMA, } \\
\text { 2014). } \\
\text { Triangulação dos Dados } \\
\text { (MARTINS, 2008; STAKE, } \\
\text { 2011). }\end{array}$} \\
\hline $\begin{array}{l}\text { 2. Analisar a } \\
\text { concepção de EA na } \\
\text { visão do corpo } \\
\text { docente. }\end{array}$ & $\begin{array}{c}\text { Qual é o perfil } \\
\text { da concepção } \\
\text { de EA do corpo } \\
\text { docente? } \\
\text { Como a EA está } \\
\text { sendo abordada } \\
\text { nos planos de } \\
\text { ensino e no PPP } \\
\text { dessa Unidade } \\
\text { Escolar? }\end{array}$ & $\begin{array}{l}\text { Questionários } \\
\text { dos docentes. } \\
\text { Planos de } \\
\text { ensino. }\end{array}$ & $\begin{array}{c}\text { Questionários } \\
\text { semi- } \\
\text { estruturados. } \\
\text { Análise } \\
\text { documental. }\end{array}$ & \\
\hline $\begin{array}{l}\text { 3. Discutir as } \\
\text { possibilidades de } \\
\text { impactos da nova } \\
\text { política proposta pelo } \\
\text { Currículo da Cidade } \\
\text { inspirada na Base } \\
\text { Nacional Comum } \\
\text { Curricular em EA. }\end{array}$ & $\begin{array}{c}\text { A EA foi } \\
\text { contemplada no } \\
\text { Currículo da } \\
\text { Cidade inspirada } \\
\text { na BNCC? }\end{array}$ & $\begin{array}{l}\text { Referenciais da } \\
\text { PMSP. }\end{array}$ & $\begin{array}{c}\text { Análise } \\
\text { documental. }\end{array}$ & $\begin{array}{l}\text { Análise de conteúdo } \\
\text { (BARDIN, 1977). }\end{array}$ \\
\hline
\end{tabular}

Fonte: dados da pesquisa, adaptado de Mazzon (1981 p.54) 
Optou-se pela triangulação dos dados dos resultados permitindo-se que o fenômeno estudado fosse visto por três fontes distintas: os documentos curriculares da PMSP, os resultados obtidos nos questionários dos docentes e os resultados dos discentes, trazendo a compreensão sobre Educação Ambiental e meio ambiente (MARTINS, 2008; STAKE, 2011).

Por fim, para responder se a política pública educacional, representada pelo currículo adotado no município de São Paulo, subsidia a corrente de EA crítica a partir da experiência do Projeto Ocupe a Praça, também utilizou-se uma abordagem interdisciplinar, trazendo a integração entre os diálogos e os conhecimentos da Pedagogia, das Ciências Ambientais, das Políticas Públicas Educacionais e Ambientais, pois, segundo Philippi Jr. et al. (2000) a interdisciplinaridade é:

toda interconexão e "colaboração" entre diversos campos do conhecimento e do saber dentro de projetos que envolvem tanto as diferentes disciplinas acadêmicas como as práticas não científicas que incluem as instituições e atores sociais diversos (PHILIPPI JR. et al., 2000, p. 22).

\section{Procedimento para coleta de dados}

Os dados utilizados para essa pesquisa foram: I) os questionários realizados com os docentes; II) os questionários realizados com os discentes; III) o Projeto Político Pedagógico; IV) o Plano Especial de Ação; V) os Planos de Ensino; VI) o Currículo da Cidade. Em destaque, no Quadro 2, há os aspectos analisados nesse estudo, suas dimensões, as fontes e seus conceitos-chave.

Quadro 2: Estratégias metodológicas da pesquisa.

\begin{tabular}{|c|c|c|c|}
\hline Dimensões & \multicolumn{2}{|c|}{ Fontes dos Dados } & Conceitos-Chave \\
\hline 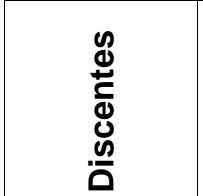 & Questionário. & $\begin{array}{l}\text { Concepção sobre o meio } \\
\text { ambiente; } \\
\text { Percepção sobre o POP. }\end{array}$ & $\begin{array}{c}\text { Macroelementos e } \\
\text { macrocompartimentos sobre o } \\
\text { ambiente (PEDRINI; COSTA; } \\
\text { GHILARDI, 2010). }\end{array}$ \\
\hline$\stackrel{\mathscr{E}}{=}$ & Questionário & $\begin{array}{c}\text { Concepção sobre o meio } \\
\text { ambiente e EA; } \\
\text { Percepcão sobre o POP. }\end{array}$ & $\begin{array}{c}\text { ns sobre melo ambiente: globallzante, } \\
\text { naturalista e antropocêntrico } \\
\text { (REIGOTA, 2007). }\end{array}$ \\
\hline $\begin{array}{l}\mathscr{U} \\
\text { வ }\end{array}$ & documental. & $\begin{array}{l}\text { Projeto Político-Pedagógico; } \\
\text { Plano Especial de Ação; } \\
\text { Planos de Ensino. }\end{array}$ & $\begin{array}{l}\text { Abordagens conservacionista, } \\
\text { pragmática e crítica }\end{array}$ \\
\hline 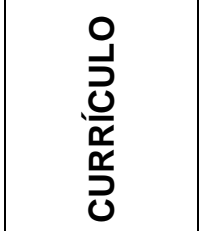 & $\begin{array}{l}\text { Questionário } \\
\text { Análise } \\
\text { documental. }\end{array}$ & $\begin{array}{l}\text { POP; } \\
\text { Projeto Mais Educação; } \\
\text { Currículo da Cidade. }\end{array}$ & $\begin{array}{c}\text { Relações entre o conhecimento } \\
\text { (FREIRE, 1987) } \\
\text { Compreensão da Prática } \\
\text { (FREIRE, 1996). }\end{array}$ \\
\hline
\end{tabular}

Fonte: dados da pesquisa. 


\section{Aplicação dos questionários com os docentes e discentes}

A amostra foi constituída por 80 participantes, entre eles 37 docentes e 43 discentes da Escola Municipal. A entrevista foi composta por perguntas abertas e fechadas. Os questionários foram aplicados aos docentes em um horário e local coletivos, onde todos se reúnem para debates do cotidiano da escola, levando cerca de quinze minutos para respondê-los. Os discentes levaram o questionário para a casa, responderam e o entregaram no dia seguinte.

Para analisar o envolvimento da unidade escolar com a Educação Ambiental foram utilizados dados obtidos nos Projetos Político-Pedagógicos (PPP) e no Projeto Especial de Ação (PEA), de 2014 a 2017, totalizando 291 páginas. O PEA e o PPP são documentos elaborados anualmente de forma coletiva por toda a comunidade escolar e são importantes por nortear a construção do conhecimento escolar de modo sistematizado.

Em relação ao currículo foram analisados os referenciais da PMSP quanto à presença de EA, totalizando 2263 páginas, dentre eles: I) Orientações Curriculares São Paulo (2007a); II) os Direitos de Aprendizagem do Ciclo Interdisciplinar e Autoral (SÃO PAULO, 2016a); III) os Direitos de Aprendizagem do Ciclo Interdisciplinar e Autoral - das disciplinas de: Ciências, São Paulo, (2016b); Língua Portuguesa, São Paulo (2016c); Língua Inglesa, São Paulo (2016d); História, São Paulo (2016e); Matemática, São Paulo (2016f); Geografia, São Paulo (2016g); Arte, São Paulo, (2016h); Educação Física, São Paulo, (2016i); IV) Currículo da Cidade das disciplinas: Ciências, São Paulo (2017a); Arte, São Paulo (2017b); Educação Física, São Paulo (2017c); Geografia, São Paulo (2017d); História, São Paulo (2017e); Língua Inglesa, São Paulo (2017f); Língua Portuguesa, São Paulo (2017g); Tecnologia de Aprendizagem, São Paulo (2017h) e Matemática, São Paulo (2017i).

\section{Procedimentos da análise dos dados}

Os dados obtidos foram tratados conforme o método da análise de conteúdo de Bardin (1977, p. 38), que representa "um conjunto de técnicas de análise das comunicações que utiliza procedimentos sistemáticos e objetivos de descrição do conteúdo das mensagens", tendo como intenção "inferir conhecimentos relativos às condições de produção".

Essa metodologia de pesquisa permitiu a realização de descrições sistemáticas, qualitativas ou quantitativas, ajudando a reinterpretar as mensagens e atingir uma compreensão de seus significados em um nível que vai além de uma leitura comum. Segundo Olabuenaga e Ispizúa (1989.p.12), a análise de conteúdo 
é uma técnica para ler e interpretar o conteúdo de toda classe de documentos que, analisados adequadamente, nos abrem as portas ao conhecimento de aspectos e fenômenos da vida social de outro modo inacessíveis.

A análise de conteúdo, em sua vertente qualitativa, parte de uma série de pressupostos, os quais, no exame de um texto, servem de suporte para captar seu sentido simbólico. Esse sentido nem sempre é manifesto e seu significado não é único, podendo ser enfocado em função de diferentes perspectivas (OLABUENAGA; ISPIZÚA, 1989).

No início de cada questionário apresenta-se uma questão de grande relevância para a pesquisa, "O que é o meio ambiente?", em que os respondentes se expressam por meio de um desenho (Esquema 1). A análise de dados foi feita de modo qualitativo, realizando uma articulação entre as categorias, destacando como o sujeito estudado percebe seu meio e suas inter-relações de dependência, conforme esquema de Pedrini, Costa, e Ghilardi 2010).

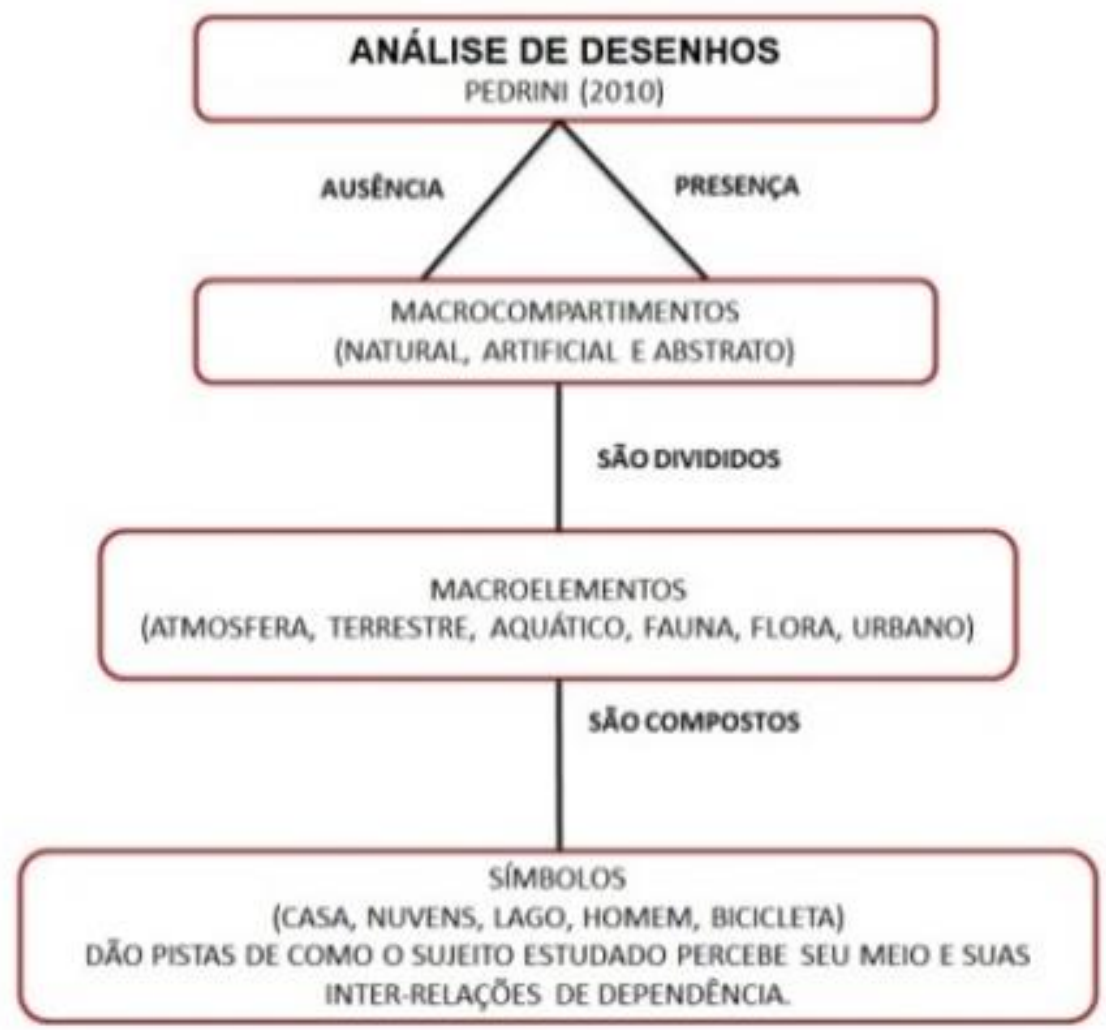

Esquema 1: Análise dos desenhos sobre: "o que é meio ambiente?".

Fonte: Pedrini, Costa e Ghilardi (2010). 
A segunda questão foi "O que se entende por EA?", onde os registros apontam sobre qual é a provável concepção de EA no grupo dos docentes. Para investigar os referenciais da PMSP utilizou-se análise documental. Segundo Bardin (1977), a informação contida nos documentos acumulados tem como objetivo dar forma conveniente e representar de outro modo a informação em estudo, obtendo o máximo de informação.

Após a leitura flutuante e a identificação da informação, foi realizada uma classificação em categorias (globalizante, conservacionista ou antropocêntrica), baseada na concepção de Reigota (2007) sobre a EA. Na qual a visão naturalista, representa o meio ambiente apenas por seus aspectos naturais (é a natureza intocada); a visão antropocêntrica, na qual o meio ambiente é caracterizado de forma utilitarista, somente como fonte de recursos naturais; e a visão globalizante, em que o meio ambiente é integrado pela natureza e sociedade, favorecendo a alteridade. As demais questões dos questionários trouxeram subsídios para analisar o POP e o currículo do município de São Paulo.

Segundo Bardin (1977 p. 46) o objetivo de uma análise documental é "a representação condensada da informação para consulta e armazenagem". Desse modo, estabeleceu-se o seguinte roteiro: I) Identificar os documentos (data e tipo do documento); II) condensar as ideias principais contidas nos documentos; III) verificar a presença das concepções de EA nos documentos e, posteriormente, classificá-las em Representação Social globalizante, naturalista ou antropocêntrica; IV) analisar os registros do Projeto Ocupe a Praça nos documentos oficiais da unidade escolar.

\section{Resultados e Discussão}

Para dar clareza aos resultados obtidos, optou-se por apresentar os resultados da seguinte forma: a) POP e as intervenções realizadas com seus reflexos socioambientais; b) docentes e suas representações; c) discentes e suas representações; d) síntese dos resultados dos PEA, PPP e planos de ensino, bem como, avaliação crítica da política pública educacional adotada no município de São Paulo por meio da proposta Currículo da Cidade.

\section{a) POP e as intervenções realizadas com seus reflexos socioambientais}

O Projeto Ocupe a Praça, produto do Trabalho Colaborativo de Autoria, (SÃO PAULO, 2014a), mostrou-se alinhado com as políticas públicas educacionais e ambientais, (BRASIL, 1999; BRASIL, 2013; SÃO PAULO, 2014a, 2016a). O alinhamento se deu ao se apresentar um trabalho interdisciplinar com intervenção social, convocando a comunidade para o engajamento e a responsabilização em relação à revitalização, conservação e preservação do meio ambiente e ao estimular o exercício da cidadania para o desenvolvimento de uma consciência crítica (FREIRE, 1996). 
Diversas ações pedagógicas em EA implementadas na praça Dr. José Ória pela escola municipal, foram realizadas a partir da construção coletiva entre os docentes, os discentes, a Subprefeitura do Butantã e a Secretaria do Verde e do Meio Ambiente. Toda a comunidade foi beneficiada com a revitalização e a conservação desse espaço público (Figura 3). Os resultados das atividades estão em destaques no Quadro 3.

Após essas intervenções a Praça Dr. José Ória mostrou-se mais vistosa e utilizável (Quadro 3). O engajamento de todos chamou a atenção tanto da comunidade escolar quanto da comunidade localizada no entorno da praça para o respeito e preservação do espaço público e para a ocupação desse espaço. Na visão topofílica, segundo Tuan (2012), o espaço se torna lugar, favorecendo o desenvolvimento de memória afetiva em relação à praça.

Tornou-se comum observar pessoas circulando normalmente, sentandose perto dos lagos e contemplando a natureza, fazendo ginástica, treinando dança ou, simplesmente, utilizando a praça como um caminho alternativo para acessar os pontos de ônibus na Avenida Professor Francisco Morato, rumo à estação do Metrô.

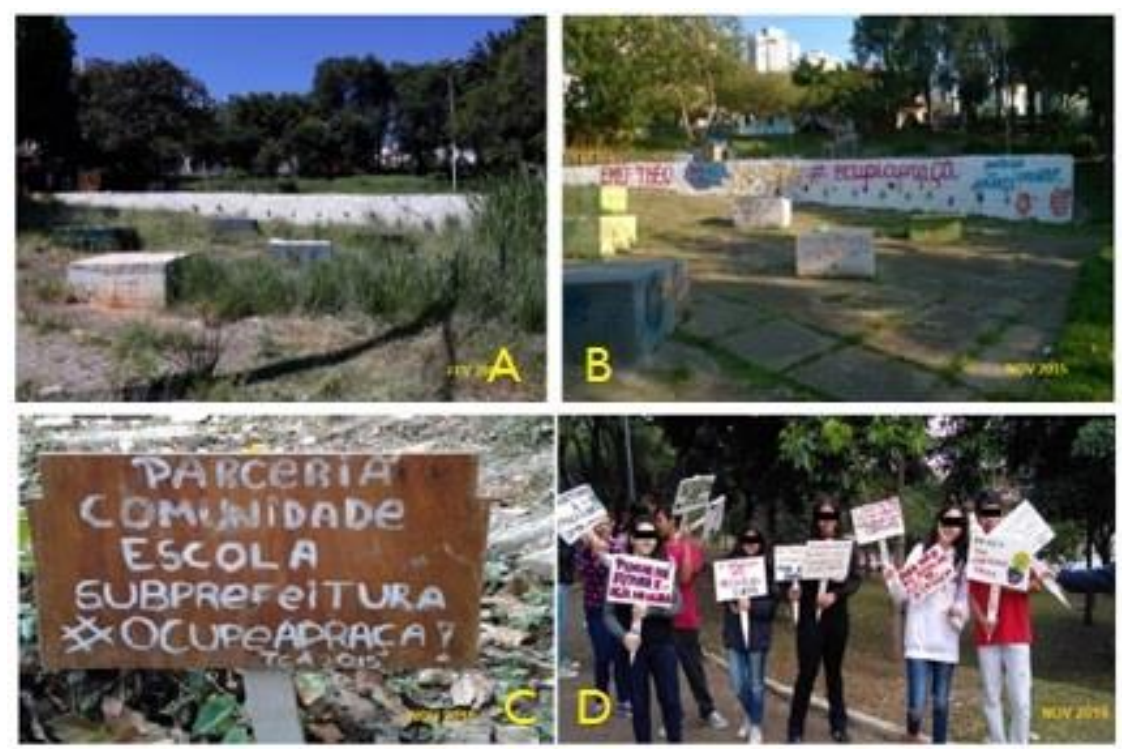

Figura 3: Praça Dr. José Ória - Vila Sônia, Butantã (São Paulo, SP). Em a): imagem antes da intervenção social (2015); em (b): imagem após a intervenção social (2015); em c) placas elaboradas pelos discentes; em d) discentes participando das atividades.

Fonte: acervo do POP. 
Quadro 3: Resultados das intervenções realizadas na Praça Dr. José Ória, São Paulo - SP, realizada pela Escola Municipal de Ensino Fundamental Desembargador Theodomiro Dias.

\begin{tabular}{|c|c|}
\hline $\begin{array}{c}\text { Reuniões com ambientalistas da Região e } \\
\text { UE }\end{array}$ & Ocupação do espaço para mostras culturais \\
\hline $\begin{array}{c}\text { Carta ofício encaminhada à Subprefeitura } \\
\text { do Butantã }\end{array}$ & Oficinas de grafite \\
\hline $\begin{array}{l}\text { Carta ofício encaminhada à Secretaria do } \\
\text { Verde e do Meio Ambiente }\end{array}$ & Pintura da quadra \\
\hline $\begin{array}{c}\text { Reunião com a Subprefeitura, discentes e } \\
\text { docentes }\end{array}$ & Pintura das escadarias \\
\hline Confecção de placas de aviso & Abertura dos lagos \\
\hline Análise do solo da praça & Inserção de peixes \\
\hline Análise da água dos lagos & Rearborização com várias espécies de plantas \\
\hline Levantamento da biodiversidade vegetal & Retirada dos resíduos de toda a área da praça \\
\hline Apresentação de saraus e cirandas & Observação e identificação dos insetos \\
\hline Rodas de leituras e reflexões ambientais & Apresentações musicais \\
\hline Realização de jogos de xadrez & $\begin{array}{l}\text { Realização de jogos de futebol, ginástica e } \\
\text { danças }\end{array}$ \\
\hline $\begin{array}{l}\text { Apresentação de dança folclórica } \\
\text { japonesa realizada por pessoas da } \\
\text { comunidade do entorno }\end{array}$ & $\begin{array}{l}\text { Realização de festas juninas da comunidade } \\
\text { escolar }\end{array}$ \\
\hline $\begin{array}{c}\text { Ação de ambientalistas relacionados com } \\
\text { permacultura }\end{array}$ & Confecção de canteiros \\
\hline Levantamento histórico da praça & Atividades Interdisciplinares \\
\hline
\end{tabular}

Fonte: dados da pesquisa.

O POP revelou que, por meio da interdisciplinaridade, todos os atores de diversas áreas envolvidos puderam olhar os problemas da praça, tentando buscar soluções. Essa prática é um dos objetivos a serem atingidos pela área de Ciências Ambientais (BRASIL, 1999; LEFF, 2000; SÃO PAULO, 2014a; SÃO PAULO, 2016a).

\section{b) docentes e suas representações}

No grupo dos docentes, um total de $41 \%$ tem o nível superior completo, $38 \%$ fizeram pós-graduação lato sensu; $16 \%$ concluíram o mestrado e $5 \%$ possuem o doutorado. A faixa etária dos respondentes analisados variou entre 25 a 68 anos, sendo que o maior número de docentes (18 estavam na faixa mais jovem de 25 a 35 anos, e 7 na faixa de 36 a 45 anos), podendo sugerir pouco tempo de formação ou de formação continuada.

A formação continuada é essencial para dar prosseguimento ao desenvolvimento profissional. Ela traz a compreensão das especificidades da 
rede municipal e estimula 0 docente a contribuir com seus saberes nos espaços coletivos. É nessa formação que podem surgir reflexões, debates e questões estimulando ações que podem levar ao amadurecimento profissional do docente e, em consequência, à melhoria da qualidade do ensino fundamental (FREIRE, 1996; SÃO PAULO, 2007a; SÃO PAULO, 2014c).

Entre os docentes que responderam a pesquisa cerca de $50 \%$ atuaram diretamente no POP e $26 \%$ atuaram parcialmente, perfazendo um total de $76 \%$. Por motivos diversos, $24 \%$ dos docentes não participaram do Projeto Ocupe a Praça.

Mais de $90 \%$ dos respondentes, incluindo aqueles que não participaram do POP, acreditam que a Praça Dr. José Ória é um espaço significativo, que pode e deve ser usado como ampliação da sala de aula para a realização de atividades escolares, incentivando a EA e estreitando relações com a natureza, corroborando com Baeder et al., (2000) que afirma que as atividades em praças estimulam o contato com natureza e incentivam o ativismo ambiental.

Os respondentes acreditavam que trabalhos em praças contribuem para fortalecer a ideia de relações. O que vai na direção do trabalho de Almeida, Bicudo, Borges (2004), cujas reflexões destacam que ações em EA devem ser desenvolvidas em praças, principalmente, aquelas próximas às escolas.

Ao serem questionados sobre a importância dos debates em EA responderam, em unanimidade, de forma positiva. Tendendo, de uma forma geral, à uma visão mais crítica, conforme o exemplo a seguir:

"os debates são importantes porque contribuem para passar de uma perspectiva conservacionista à uma compreensão crítica entre as relações de poder, a ocupação, a destruição e preservação dos espaços."

Os docentes acreditavam que diversos temas sobre a EA são relevantes por trazerem reflexões e entendimento do mundo, conscientização sobre os cuidados do meio ambiente e sustentabilidade das cidades e, acima de tudo, desenvolverem uma visão crítica para a tomada de decisões e resoluções de problemas (REIGOTA, 2017).

Neste sentido, as praças podem ser instrumentos sensibilizadores importantes, por serem espaços de sociabilidade e promovem encontros e convívios, tendo como função a formação política, social e econômica das cidades (CALDEIRA, 2007). Portanto, utilizá-las para o desenvolvimento de trabalhos de EA, bem como, para a difusão e a popularização da ciência, dá possibilidades para as pessoas exercerem sua cidadania, percebendo o local como um espaço significativo para a preservação cultural, participando de modo efetivo do mundo em que vivem (FREIRE, 1996; SAITO, 2012; TUAN, 2012). 


\section{Visão de Meio ambiente}

Os docentes fizeram um desenho para responder qual era seu entendimento sobre meio ambiente. Dos 37 respondentes foram obtidos 35 desenhos que representam a concepção de meio ambiente. Todos os desenhos foram analisados e classificados entre três categorias: os macrocompartimentos naturais, os artificiais e os abstratos (PEDRINI; COSTA; GHILARDI, 2010). Posteriormente, foram classificados nas categorias globalizante, naturalista e antropocêntrico (REIGOTA, 2007).

Em destaque um dos desenhos (Figura 4) apresentou os seguintes símbolos: seres humanos, lata de lixo, carro, poluição, bicicleta, fábrica, rua, casa, prédio, árvore, frutos e planeta Terra. Esses símbolos se encaixam nos macroelementos atmosférico, aquático, terrestre, urbano, fauna e flora que estão representados pelos macrocompartimentos natural e artificial (Esquema 2). O desenho indica uma interação entre a natureza e a sociedade, pois apresenta na mesma imagem os macrocompartimentos artificial e natural.
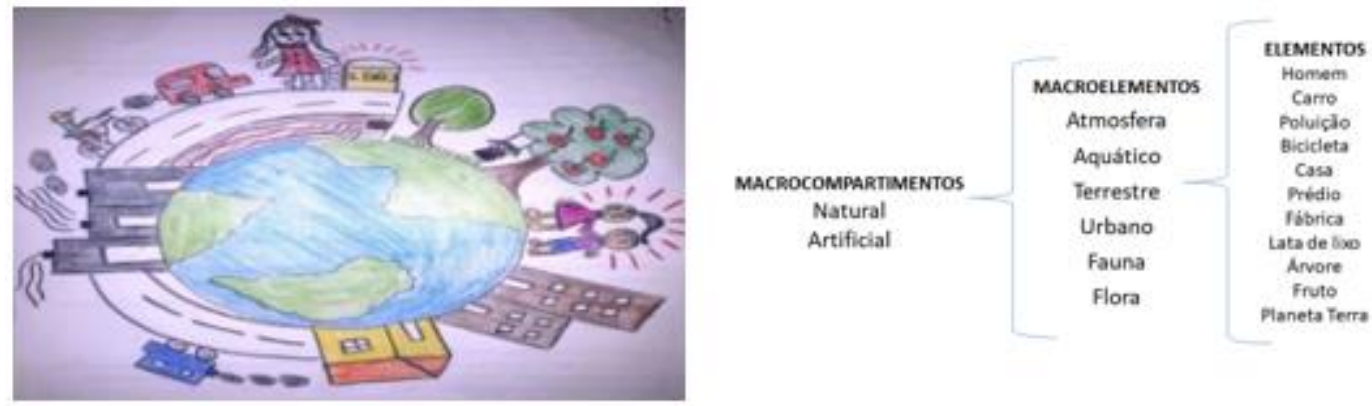

Figura 4: Desenho realizado por um docente que representa uma visão globalizante do que é o meio ambiente. No Esquema (2), macrocompartimentos, macroelementos e símbolos destacados do desenho. Fonte: dados da pesquisa (2018).

A visão globalizante também pode ser confirmada pelo símbolo "humano", presente em $80 \%$ dos desenhos. A presença de seres humanos pode sugerir que eles fazem parte do ambiente, estando integrado com a natureza e com a sociedade. Nota-se, então, a complexidade que envolve as questões ambientais contemporâneas e a necessidade da união de vários atores da sociedade para se debruçarem em busca de soluções (LEFF, 2000).

A visão globalizante sobre o meio ambiente foi observada em $88 \%$ dos desenhos, um número expressivo dos docentes analisados. Em menor proporção $(6 \%)$ alguns desenhos apresentaram uma visão naturalista. A Figura 5 apresenta os símbolos ave, sol, flor, árvore e nuvem. Eles se encaixam nos macroelementos atmosférico, flora e terrestre e macrocompartimento natural. 

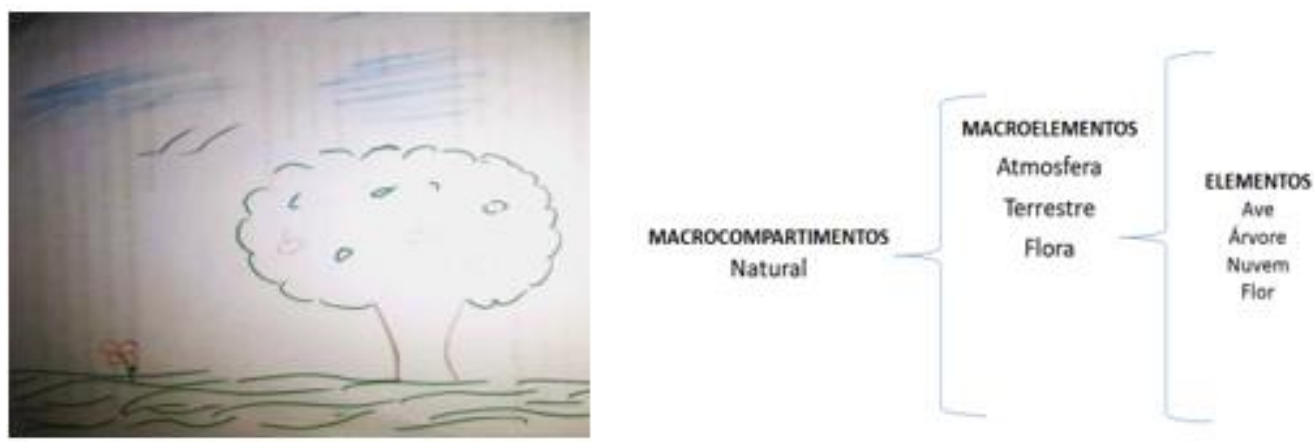

Figura 5: Desenho realizado por um docente que representa uma visão naturalista do que é o meio ambiente. No Esquema (3), macrocompartimentos, macroelementos e símbolos destacados do desenho. Fonte: dados da pesquisa (2018).

Observou-se também um desenho com macrocompartimento artificial, com o símbolo latões de reciclagem (3\%) e um desenho natural e abstrato com os símbolos planeta Terra e coração (3\%). Não houve ocorrência de desenhos apenas com o macrocompartimento abstrato.

Esses resultados diferem dos encontrados nas pesquisas de Trevisol (2004); Ribeiro, Lobato, Liberato (2010) e Costa et al. (2012), nas quais a visão dos docentes sobre o meio ambiente foi predominantemente naturalista, sinônimo de natureza intocada, evidenciando apenas os aspectos naturais. O ser humano é um mero espectador e não se vê responsável pelos problemas ambientais.

Ressaltam ainda que, apesar de os docentes desenvolverem temas sobre meio ambiente em suas aulas, a abordagem é fragmentada, mantendo o modelo tradicional de educação, desvinculada da realidade próxima ao estudante.

Para Santana, (2018), a falta de integração por todas as disciplinas escolares sobre o tema meio ambiente contribui para a formação de uma visão naturalista. Além disso, se a EA não for introduzida desde a infância como uma teia de inter-relações que inclua os seres humanos e o ambiente, essa visão se perpetuará.

Numa visão globalizante o ser humano não se vê apartado da natureza. Isso representa um passo importante para a sua responsabilização pelas ações negativas causadas ao ambiente. Desse modo, busca-se atender um dos objetivos da Política Municipal de Educação Ambiental de São Paulo (SÃO PAULO, 2014a) em construir uma sociedade ecologicamente responsável.

Para tanto, deve-se estimular e incentivar a participação dos indivíduos em projetos e ações, sugerindo responsáveis permanentes para a proteção e preservação do meio ambiente, visando o estímulo da cidadania, caminhos que apontam para uma EA crítica (LAYRARGUES; LIMA, 2014; REIGOTA, 2017). 
Por isso, é importante conhecer a concepção do grupo de docentes sobre o tema, visto que essa essência refletirá na formação dos estudantes durante a realização das atividades. Assim sendo, qualquer atividade de EA que busque uma reflexão sobre as relações homem-sociedade-natureza deve vir ao encontro da construção de valores e atitudes que permitam a transformação da sociedade (REIGOTA, 2017).

\section{Visão de Educação Ambiental}

As diversas respostas sobre o significado de EA foram analisadas de acordo com as Representações Sociais e classificadas em três categorias: naturalista, antropocêntrico e globalizante (REIGOTA, 2007) e posteriormente analisadas de acordo com as macrotendências de EA no Brasil (LAYRARGUES; LIMA, 2014).

Baseando-se nas classificações de Reigota (2007) as concepções em relação ao tema indicaram que cerca de $73 \%$ dos respondentes têm uma visão globalizante, em que o meio ambiente é integrado pela natureza e sociedade. Cerca de $22 \%$ têm uma visão naturalista, na qual o meio ambiente é caracterizado apenas por seus aspectos naturais, trazendo a ideia de uma natureza intocada. E 5\% têm uma visão antropocêntrica, na qual o meio ambiente é caracterizado como fonte de recursos naturais para a sobrevivência do ser humano.

Os limites de cada uma das categorias citadas por Reigota (2007) nem sempre estão claramente definidos nas informações coletadas, pois os sujeitos não são apenas "isso" ou "aquilo", rigorosamente. Entretanto, algumas respostas se classificam com clareza. A concepção de uma das professoras entrevistadas veio ao encontro das categorias de RS (REIGOTA, 2007), em uma visão antropocêntrica, na qual os recursos naturais são foco para a sobrevivência do homem pois, para ela, EA é:

"um conjunto de informações sobre a convivência. Como conviver com o meio e os recursos naturais de modo equilibrado."

Para outros professores a visão naturalista esteve presente em suas concepções, trazendo a ideia de que o ser humano é apenas um espectador da natureza, ao afirmarem que:

\footnotetext{
"é o respeito ao meio ambiente";

"é o estudo do meio ambiente";
} 
A maioria dos respondentes tem uma visão globalizante, por entender que a EA não é vista apenas nos aspectos ecológicos, mas também políticos, sociais, econômicos e culturais. A Educação Ambiental:

"é educar a partir das reflexões sobre as relações existentes entre o homem e seu entorno. É pensar coletivamente sobre as formas de interação e buscar soluções para a vida em comunidade".

"são ações e projetos de conscientização a respeito de como o modelo atual de desenvolvimento afeta e prejudica a natureza, as relações sociais, as comunidades e os próprios indivíduos".

Em relação à tendência de EA consonante entre os docentes, segundo Layrargues e Lima (2014), considerando o referencial teórico da macrotendência que disputa a hegemonia do campo EA no Brasil conservadora, pragmática e crítica - verificou-se que houve uma predominância da concepção crítica nas respostas dos docentes. Em destaque, no Quadro 4, algumas concepções dos docentes.

Quadro 4: Concepção de Educação Ambiental no discurso dos docentes.

\begin{tabular}{|c|c|c|}
\hline CONSERVACIONISTA & PRAGMÁTICA & CRÍTICA \\
\hline $\begin{array}{c}\text { "é o conhecimento sobre o } \\
\text { funcionamento do meio } \\
\text { ambiente." }\end{array}$ & $\begin{array}{l}\text { "é um conjunto de } \\
\text { informações sobre a } \\
\text { convivência com o meio } \\
\text { ambiente, como conviver } \\
\text { com os recursos naturais } \\
\text { de modo equilibrado." }\end{array}$ & $\begin{array}{l}\text { "engloba toda a fauna e flora, } \\
\text { assim como os processos do ser } \\
\text { humano na natureza. É a } \\
\text { intervenção humana: fábricas, } \\
\text { poluentes, desmatamento e } \\
\text { contaminação." }\end{array}$ \\
\hline $\begin{array}{c}\text { "é a orientação aos } \\
\text { estudantes visando a } \\
\text { conservação do meio } \\
\text { onde vivem, conservação } \\
\text { da natureza para viver em } \\
\text { equilíbrio com o } \\
\text { ambiente." }\end{array}$ & $\begin{array}{c}\text { "é um processo de } \\
\text { construção e conhecimento } \\
\text { de atitudes para a } \\
\text { preservação/manutenção } \\
\text { de um ambiente sadio e } \\
\text { sustentável." }\end{array}$ & $\begin{array}{c}\text { "é o trabalho de conscientização } \\
\text { da pegada ambiental ou pegada } \\
\text { ecológica de cada indivíduo e a } \\
\text { capacitação e oportunização de } \\
\text { contribuir, de modo consciente, } \\
\text { para uma ação contínua na } \\
\text { contribuição de um planeta } \\
\text { sustentável." }\end{array}$ \\
\hline $\begin{array}{l}\text { "é a educação em que o } \\
\text { homem consegue agir } \\
\text { para ter um ambiente } \\
\text { melhor, preservar a } \\
\text { natureza e parar ou } \\
\text { diminuir a poluição." }\end{array}$ & $\begin{array}{c}\text { "é voltada para a } \\
\text { conscientização das } \\
\text { pessoas acerca de temas } \\
\text { como preservação } \\
\text { ambiental, lixo, poluição, } \\
\text { proteção dos animais, } \\
\text { dentre outros." }\end{array}$ & $\begin{array}{c}\text { "é um processo em que se } \\
\text { constrói com alunos e } \\
\text { sociedades conceitos, maneiras } \\
\text { de pensar e práticas referentes } \\
\text { às relações humanas com o } \\
\text { meio (diversos biomas, cidades, } \\
\text { espaços), com o intuito de } \\
\text { equilibrar e melhorar essas } \\
\text { relações." }\end{array}$ \\
\hline
\end{tabular}

Fonte: Dados da pesquisa (2018), utilizando classificação de Layrargues e Lima (2014). 
A EA crítica tem crescido na última década, possivelmente devido aos avanços nos marcos legais, com grandes esforços de movimentos sociais, organizações não governamentais, acadêmicos e grupo de pessoas que se sentem responsáveis por consolidá-la nas próximas décadas como um campo emergente (REIGOTA, 2012).

A EA pode ser entendida de acordo com várias vertentes e, talvez por isso, as respostas dos docentes tenham sido variadas. Nesse grupo um número reduzido apresentou visão fragmentada, parcial e insuficiente sobre o tema, excluindo a participação humana nas questões. A maioria tem visão ampla, social e política em que o homem, no exercício de sua cidadania, deve atuar politicamente em busca das transformações (FREIRE, 1987), ratificando a ideia de que a macrotendência de EA crítica vem ganhando um lugar efetivo e permanente no Brasil (LAYRARGUES, 2014).

Essa visão globalizante de EA apresentada por parte dos docentes deve-se ao fato de possuírem uma Jornada Especial Integral de Formação (JEIF) para a execução do Projeto Especial de Ação e pela participação no Projeto Político Pedagógico da unidade escolar que, durante todo o ano letivo, em 146 horas, participaram de leituras, debates, rodas de conversas sobre saúde, ambiente, questões etnorraciais, gênero, política, intervenções e relações que se estabelecem na sociedade (SÃO PAULO, 2007c). Destaca-se a importância desse momento entre todos os docentes, resultando em uma visão ampliada sobre a definição do que é meio ambiente e de Educação Ambiental.

Entretanto, nem todos os docentes dessa UE e de toda a rede municipal possuem a JEIF como jornada de trabalho. Sendo assim, faz-se necessário uma formação continuada em EA para esses profissionais, principalmente, para aqueles que não têm a EA contemplada em seu PPP ou PEA. Essa formação está prevista na Política Nacional de Educação Ambiental (BRASIL, 1999) e nas Diretrizes Curriculares Nacionais para a Educação Ambiental (BRASIL, 2013).

Dall'Onder (2018) aponta a importância desta formação para o desenvolvimento intelectual do docente e o momento de sua realização. Devido a jornada dupla de trabalho, os docentes, não conseguem realizar cursos em outro horário a não ser durante o horário de trabalho, portanto, indica a necessidade de se realizar durante o horário do trabalho.

Apesar do envolvimento da maioria dos docentes nos trabalhos de EA na UE ainda é expressivo o número de professores que não desenvolvem essas atividades, mesmo sendo previstas pelas políticas ambientais e educacionais (BRASIL, 1999; SÃO PAULO, 2014a; SÃO PAULO, 2016b).

É possível que estes docentes não se percebam como educadores ambientais, corroborando com Otero e Neiman (2015), pois necessitam superar-se como agentes transformadores da sociedade. Se todos os indivíduos brasileiros têm direito à EA, segundo a legislação brasileira, é 
necessário que os docentes executem ações, visto que exercem um papel fundamental para estimular a percepção ambiental e desenvolver as habilidades dos discentes (FARIAS et al., 2017).

Dentre as ações que um educador pode e deve realizar para tentar cumprir o seu papel social no contexto escolar, destacam-se: os debates sobre as relações do homem com o meio ambiente; as práticas de EA em praças públicas; o cultivo de hortas; leituras de temas onde o homem seja 0 protagonista das atitudes positivas à natureza; cuidados com os espaços ocupados dentro e fora da escola; conscientização dos estudantes sobre a prática da cidadania, trazendo a compreensão de seu papel junto ao poder público; promoção de um ambiente de trabalho saudável para o bem estar de todos.

Em relação aos temas dos trabalhos em EA, o "ambiente" e a ocupação do espaço público, com as inter-relações entre as pessoas e o território, aparecem com maior relevância entre os docentes, indicando a influência do POP nessa comunidade. O consumo consciente, a biodiversidade e a poluição também estão presentes nos trabalhos desenvolvidos.

A interdisciplinaridade foi apontada pelos docentes como um modo de se trabalhar as questões relacionadas ao ambiente, pois auxilia os estudantes a perceberem o meio, a reconhecerem os problemas e buscarem as soluções (BRASIL, 1999; PHILIPPI JUNIOR et al., 2000).

Assim sendo, cerca de $70 \%$ dos respondentes declararam que trabalham de modo interdisciplinar. Dentre os temas foram destacados: desperdício, poluição, desmatamento, atitudes cotidianas, habitação, extinção de animais. A ocupação do espaço público e suas relações se destacam em maior número. Esse último tema pode ser um indicativo do POP desenvolvido na unidade escolar.

O POP é mais um trabalho que, junto a outros estudos, reforça a importância do educador ambiental e da EA (FARIAS et al., 2017; LEITE, 2015; SAITO, 2012; OTERO; NEIMAN, 2015). Em seu quarto ano de existência e novos desafios, vinculado ao PEA e ao PPP da unidade escolar, garante seu desenvolvimento e proporciona abertura ao docente para discutir com seus educandos quais serão os futuros trabalhos a serem realizados.

O estudo deste caso trouxe uma contribuição para as políticas públicas educacionais, ressaltando a importância de políticas públicas como a "Mais Educação São Paulo" (SÃO PAULO, 2014a), indicando que nenhuma educação é neutra e que é possível uma escola trabalhar além de seus muros para desenvolver atividades que possam levar os estudantes a uma EA crítica (FREIRE, 1996; REIGOTA, 2017; LAYRARGUES; LIMA, 2014). 


\section{c) discentes e suas representações}

Os 43 estudantes que responderam à pesquisa cursavam entre $080 \mathrm{e} o$ 90 ano do ensino fundamental, com faixa etária entre 13 a 16 anos, sendo que maioria (30) tinham 14 anos. A maioria dos estudantes (10) mora no bairro da Vila Sônia e os demais em outros bairros próximos da escola, como Jardim Colombo (9), Paraisópolis (8), Vila Morse (5), Butantã (3) e Monte Kemel (8).

A Praça Dr. José Ória se tornou visível ao discente após o desenvolvimento do TCA e revelou-se como um território que possibilita o exercício da intensa relação entre o ser humano e o meio ambiente, levando à construção de uma consciência ambiental, podendo despertar a Topofilia (TUAN, 2012).

A partir dessas intervenções, a convivência e as relações que se estabeleceram na praça trouxeram o entendimento aos discentes de que esse espaço faz parte do meio ambiente. Reconheceram a praça como um território urbano com vários representantes da flora e da fauna, incluindo o homem, onde a natureza está presente o tempo todo, apontando uma visão globalizante sobre o meio ambiente (REIGOTA, 2007).

Todos os respondentes disseram que conhecem a Praça Dr. José Ória. Apenas quatro estudantes declararam que não tiveram aula na praça. Os demais afirmaram que realizaram atividades de variadas disciplinas, incluindo leituras de romances ou poemas, debates de inúmeros temas, mutirão de limpeza, plantio de mudas, dentre outras atividade que trouxeram a compreensão sobre as relações entre os seres que lá habitam ou circulam, ações normalmente realizadas por ativistas ambientais, desenvolvendo 0 entendimento sobre a importância da preservação do espaço público (BAEDER et al., 2000).

Além da utilização para as atividades escolares, todos os respondentes afirmaram que fazem uso desse espaço de variadas formas, dentre elas: utilizar como passagem, jogar futebol e treinar danças, levar o cachorro para passear, contemplar a natureza, encontrar amigos, descanso ou recreação.

Em unanimidade os estudantes acreditam que a praça é um ótimo lugar para se aprender, pois amplia a sala de aula com um espaço bonito que oferece um "movimento" diferente, percebendo o ambiente por outra perspectiva. Essa percepção ambiental pode incentivar a compreensão crítica, os diálogos e debates sobre questões ambientais (FARIAS et al., 2017).

Na percepção ambiental a Topofilia (TUAN, 2012) - amor ao lugar pôde ser captada nas respostas dos estudantes, ao serem questionados sobre o sentimento ao comtemplar a praça durante as atividades escolares ou quando está limpa e bem cuidada. Alguns estudantes fizeram as seguintes revelações:

"fico feliz em ver a praça arrumada, pois ficar em um ambiente agradável é muito legal. Além disso, fico feliz por saber que nós estamos cuidando do nosso ambiente." 
"tenho uma satisfação enorme, pois graças à ajuda de nós alunos, professores e comunidade conseguimos deixá-la assim. Vamos conseguir ainda mais progresso para o nosso Projeto Ocupe a Praça. Ele tem uma relação entre o cuidado e a preservação do meio ambiente."

A beleza do lugar, as cores, os contornos, cheiros e sensações evocam um sentimento topofílico (TUAN, 2012). A praça se destaca como símbolo urbano, palco de eventos históricos, espaço agregador (CALDEIRA, 2007). Também oferece aos educandos a possibilidade de perceberem a complexidade existente nas relações entre o homem e o ambiente, bem como, nas relações sociais e na responsabilização dos cuidados de espaços públicos (REIGOTA, 2012).

Os educandos afirmaram que os frequentadores da praça ou as pessoas que moram em seu entorno, e até mesmo os próprios estudantes da escola, são responsáveis pelos resíduos que aparecem nesse espaço, com ênfase nas "pessoas que não ligam para o ambiente, que deixam as fezes de seus animais e não as recolhem e aquelas que não tem amor pela praça", indicando a falta da Topofilia (TUAN, 2012).

Os estudantes se sentem conscientes de seus atos ao participarem tanto na manutenção da praça como no exercício de sua cidadania ao reivindicarem melhorias por meio de um requerimento escrito coletivamente e direcionado sistematicamente à Subprefeitura de São Paulo (FREIRE, 1996). Incluem-se como corresponsáveis na manutenção da limpeza deste espaço público, evitando de sujá-lo. Entretanto, responsabilizam a prefeitura pela manutenção e reposição de estruturas que compõem a praça. Essa postura pode indicar que o estudante é sabedor do papel da Prefeitura Municipal de São Paulo, podendo indicar uma perspectiva de EA crítica (LAYRARGUES; LIMA, 2014).

A manutenção engloba a poda do mato de modo sistemático, a reposição de iluminação, lixeiras, aparelhos de ginástica e bancos, retirada do lixo e reposição do piso da calçada, ratificando Dall'Onder (2018), que sugere uma EA crítica capaz de viabilizar alternativas para a sustentabilidade, desenvolvendo nos estudantes a participação e a corresponsabilização pela transformação social, conservação do ambiente e manutenção da biodiversidade.

Os estudantes ainda esperam ocupar mais o espaço público, colaborar com a preservação da praça para a realização de diversos trabalhos escolares e continuar fazendo mais e melhor por ela, ratificando Almeida, Bicudo, Borges (2004), os quais afirmam que praças públicas próximas às escolas podem servir para o desenvolvimento de atividades em EA, com envolvimento da comunidade escolar. 
Diante do exposto faz-se necessário realizar uma reflexão crítica da prática educativa, trazendo o debate entre o discurso e a prática escolar e aproximar os estudantes dos problemas de sua comunidade (FREIRE, 1996).

Sendo assim, é preciso construir um currículo a partir dessas necessidades, onde todas as disciplinas sejam contempladas e vinculadas ao Projeto Político Pedagógico, com atividades sobre o meio ambiente e suas relações com a sociedade (SÃO PAULO, 2014). Deve-se também buscar a interdisciplinaridade contínua e permanente que propiciem uma visão globalizante, visando superar o entendimento fragmentado do meio ambiente (BRASIL, 1999).

\section{Visão de Meio ambiente}

Dos 43 questionários respondidos pelos discentes sobre o significado de meio ambiente foram obtidos 40 desenhos que representam a concepção dos discentes. Todos os desenhos foram analisados observando os macrocompartimentos natural, artificial e abstrato, segundo Pedrini, Costa e Ghilardi (2010) e posteriormente classificados nas categorias globalizante, naturalista e antropocêntrica (REIGOTA, 2007).

Em destaque, um dos desenhos (Figura 13) apresenta os elementos árvores, nuvens, pássaros, flores, gramas, solo e lago. Esses elementos se encaixam nos macroelementos fauna, flora, atmosférico e terrestre e no macrocompartimento natural (Esquema 4). Esse desenho indica que o estudante tem visão naturalista, pois apresenta apenas aspectos naturais do ambiente.
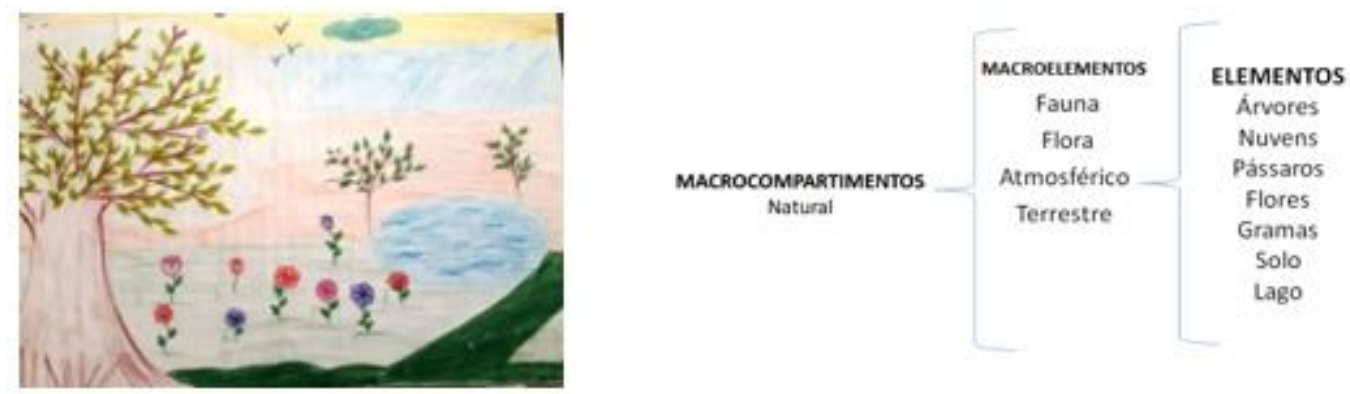

Figura 13: Desenho realizado por um discente que representa uma visão naturalista do que é o meio ambiente. No Esquema (4), macrocompartimentos, macroelementos e símbolos destacados do desenho. Fonte: dados da pesquisa (2018).

O desenho produzido na Figura 14 indica que o estudante tem visão globalizante sobre o meio ambiente, porque os aspectos naturais e artificiais foram registrados na mesma figura (REIGOTA, 2007). Os elementos destacados são: casas e prédios, nuvens, árvores, homem, rua, solo, grama e lago. Eles se encaixam nos macroelementos: atmosférico, aquático, terrestre, urbano, fauna e flora. Apresenta os macrocompartimentos natural e artificial (PEDRINI; COSTA; GHILARDI, 2010). 


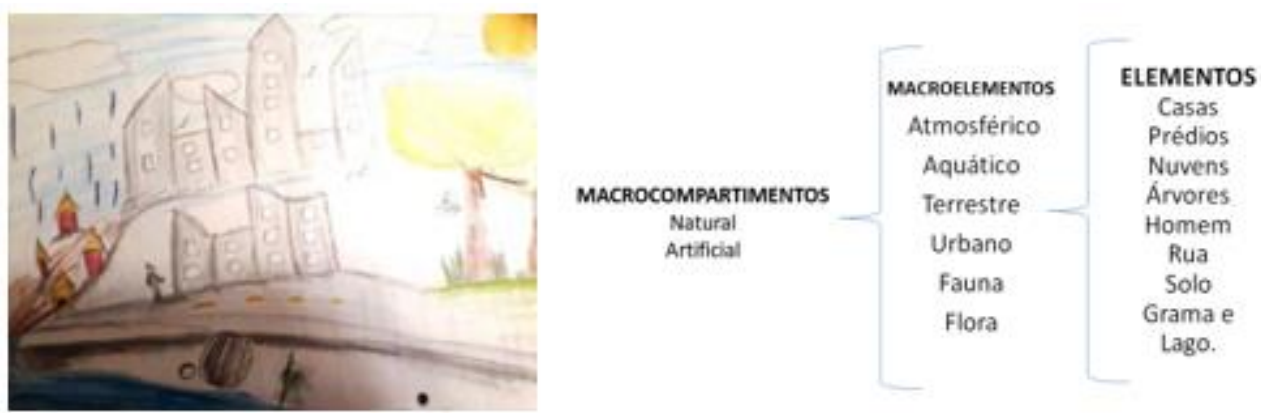

Figura 14: Desenho realizado por um discente que representa uma visão globalizante do que é o meio ambiente. No Esquema (5), macrocompartimentos, macroelementos e símbolos destacados do desenho. Fonte: dados da pesquisa (2018).

A visão globalizante sobre o meio ambiente foi encontrada em $80 \%$ dos desenhos. Assim sendo, um número expressivo dos estudantes participantes da pesquisa demonstrou uma visão ampliada sobre o meio ambiente devido à presença de macrocompartimentos naturais e artificiais. Esses resultados diferem dos outros estudos sobre percepção ambiental e representação social realizados anteriormente por Carmo, Moura, Souza (2013) e Santana (2018), com predominância de uma visão naturalista.

É possível que a visão globalizante dos discentes se deva aos trabalhos desenvolvidos em diversas disciplinas na escola e no POP por, no mínimo, dois anos. Muitos deles têm consciência de que o homem é parte integrante da natureza, porque em $45 \%$ de seus desenhos foram encontrados símbolos humanos. Em 35\% a presença humana não aparece explicitamente mas é retratada com outros símbolos, como casas, prédios, placas de sinalização, latas de lixo e carros.

Em menor porcentagem (18\%) alguns discentes demonstram uma visão naturalista, na qual o ambiente é caracterizado apenas por seus aspectos naturais. Somente um desenho apresentou macrocompartimento natural e abstrato, no qual o estudante retratou o planeta Terra e o símbolo da reciclagem (REIGOTA, 2007).

\section{d) política pública educacional adotada no município de São Paulo por meio da proposta Currículo da Cidade.}

Foi realizada uma análise documental num total de 2599 páginas referentes aos anos entre 2012 e 2017, abrangendo três categorias: tipo de documento, ideias principais e presença ou ausência da $E A^{4}$. Desse modo, foi

4 Foram analisados os Planos de Ensino, Projeto Político Pedagógico (PPP), Plano Especial de Ação (PEA) e, ainda os seguintes documentos da Secretaria Municipal de Educação: Orientações Curriculares (2007a); Mais Educação São Paulo, São Paulo (2014a); Plano de Navegador - Aluno, São Paulo (2014c); Plano de Navegador - Professor, São Paulo (2014d); Diálogo com a Rede, São Paulo (2015d); Direitos de Aprendizagem do Ciclo Interdisciplinar e Autoral - documento introdutório São Paulo (2016a); das disciplinas de: Ciências, São Paulo, (2016b); Língua Portuguesa, São Paulo (2016c); Língua Inglesa, São Paulo (2016d); História, São Paulo (2016e); Matemática, São Paulo (2016f); Geografia, São Paulo 
possível entender como a EA está sendo orientada no currículo e qual é a concepção que prevalece no município de São Paulo.

\section{Planos de Ensino}

Os planos de ensino são elaborados pelos docentes no inicio de cada ano letivo, tendo como base os documentos oficiais da SME. Apesar das orientações, $30 \%$ dos respondentes disseram que não consultaram estes documentos para a confecção de seus planos. Esse é um dado importante, pois os docentes que não fizeram uso das orientações deixaram de incorporar oficialmente a EA ou outro quesito importante dos direitos de aprendizagem.

Ao serem questionados sobre a inserção de atividades de Educação Ambiental em seus planos de ensino tivemos $38 \%$ dos docentes que a contemplaram totalmente e $32 \%$ parcialmente. Portanto, $70 \%$ dos docentes contemplaram e realizaram alguma atividade de EA. Evidentemente, 0 planejamento é um passo importante que antecede ações e, se estiver elaborado de modo conciso, pode ser revisitado e replanejado a qualquer momento. $O$ que não se registra pode cair no esquecimento e o ato de facultar qualquer atividade ou conceito se torna plausível.

Os docentes, segundo Pacheco (2003), devem ser capazes de mudar a realidade da sala de aula fazendo uma reflexão sobre sua prática durante a elaboração de currículo. Assim, torna-se necessário a busca da participação efetiva na construção de um currículo que permita seus estudantes desempenhar um papel significativo na construção do conhecimento.

Diante desse panorama ficará a cargo apenas de cada unidade escolar construir um currículo que insira a Educação Ambiental nos planos de ensino. Esse plano faz parte do currículo é o "coração da escola" devendo ser construído a partir das necessidades da escola e discutido coletivamente com sua comunidade. Desse modo, o educando poderá vivenciar sua realidade, participar ativamente de sua comunidade e transformar seu ambiente por meio de um processo educativo que propicie "um bom desempenho no mundo imediato, habilidade de criticar e transcender suas experiências culturais, capacidade de autorreflexão e compreensão da sociedade em que está inserido" (MOREIRA, 2009, p. 4).

(2016g); Arte, São Paulo, (2016h) e Educação Física, São Paulo, (2016i). E também o Currículo da Cidade das disciplinas: Ciências, São Paulo (2017a); Arte, São Paulo (2017b); Educação Física, São Paulo (2017c); Geografia, São Paulo (2017d); História, São Paulo (2017e); Língua Inglesa, São Paulo (2017f); Língua Portuguesa, São Paulo (2017g); Tecnologia de Aprendizagem, São Paulo (2017h) e Matemática, São Paulo (2017i). Esses documentos norteiam o currículo do município de São Paulo. 


\section{Projeto Político-Pedagógico e Plano Especial de Ação}

O Projeto Político Pedagógico (PPP) deve trazer em registros as intenções anuais da escola e ser construído coletivamente, com toda a comunidade escolar. Tem como objetivo dar uma direção com ação intencional, indicando propostas para serem executadas na busca de soluções para os problemas da escola. Todas as escolas do município de São Paulo têm seu PPP, que diferem entre si, pois nele estão contidas as necessidades específicas de cada unidade escolar (VEIGA, 2002; SÃO PAULO, 2016a).

O Plano Especial de Ação (PEA) é um projeto elaborado pelos educadores que serve como um instrumento de trabalho que expressam as prioridades de cada unidade escolar e deve estar voltado para as necessidades dos estudantes visando 0 aprimoramento das práticas educativas e consequente melhoria da qualidade social da educação (SÃO PAULO, 2014b).

Entre os anos de 2014 ao ano de 2016, o PPP incluiu a busca da identidade da comunidade escolar e o PEA trouxe a implantação e a solidificação do Programa de Reorganização Curricular e Administrativa, Ampliação e Fortalecimento da Rede Municipal de Ensino de São Paulo - Mais Educação São Paulo (SÃO PAULO, 2014a), que trouxe um foco na interdisciplinaridade e buscou um plano de ação pedagógica com atividades que favoreciam esse debate na escola.

A intervenção social foi destacada na execução do TCA, onde os estudantes deveriam estar atentos às questões políticas, econômicas, culturais e éticas. As palavras Educação Ambiental não estão escritas explicitamente em todo o PEA, mas a concepção do estudo do meio e suas inter-relações estiveram presentes.

O TCA trouxe um debate da apropriação de espaço público para atividades escolares, simbiose entre público e privado, responsabilidade, cooperação, compreensão de deveres e direitos que envolvem a prática cidadã, meio ambiente, preservação, parceria escola, família e comunidade do entorno. Também propôs diálogos sobre o exercício da responsabilidade, da solidariedade, da tomada de decisões, bem como na apropriação e no manejo do conhecimento culturalmente acumulado com a responsabilidade de transformação social.

Como norteadores do currículo, no ano de 2016 foram elaborados pelo município de São Paulo, os Direitos de Aprendizagem do Ciclo Interdisciplinar e Autoral, São Paulo (2016a) nas disciplinas de: Ciências, São Paulo, (2016b); Língua Portuguesa, São Paulo (2016c); Língua Inglesa, São Paulo (2016d); História, São Paulo (2016e); Matemática, São Paulo (2016f); Geografia, São Paulo (2016g); Arte, São Paulo, (2016h) e Educação Física, São Paulo, (2016i) e, em análise, percebeu-se uma concepção crítica de Educação Ambiental (Quadro 5).

É possível observar explicitamente a EA crítica na disciplina de Ciências, provavelmente porque os docentes dessa área têm, em maior número, 
formações pedagógicas a respeito do meio ambiente e suas inter-relações, bem como ocorre na disciplina de geografia. Nas demais disciplinas a EA crítica está pautada nas inter-relações do homem, natureza, sociedade e poder público.

Quadro 5: Concepção de EA (LAYRARGUES; LIMA, 2014) presentes nos "Direitos de Aprendizagem do Ciclo Interdisciplinar e Autoral" das disciplinas do ensino fundamental do município de São Paulo.

\begin{tabular}{|c|c|c|}
\hline DISCIPLINAS & EDUCAÇÃO AMBIENTAL & $\begin{array}{c}\text { CONCEPÇÃO } \\
\text { DE EA }\end{array}$ \\
\hline $\begin{array}{c}\text { Língua } \\
\text { Portuguesa }\end{array}$ & $\begin{array}{l}\text { "Usar diferentes recursos linguísticos que podem se } \\
\text { fazer instrumentos de transformação social." }\end{array}$ & EA crítica \\
\hline Língua Inglesa & $\begin{array}{l}\text { "Experiências educativas que refletem - reproduzindo } \\
\text { valores e comportamentos vigentes nas relações } \\
\text { construídas dentro e fora da escola [...]". }\end{array}$ & EA crítica \\
\hline Matemática & $\begin{array}{l}\text { "Trazer apoio às culturas e sua diversidade conduz ao } \\
\text { autoconhecimento e ao conhecimento do meio social } \\
\text { do estudante para habilitá-lo a responsabilizar-se por } \\
\text { ações sociais transformadoras [...]". }\end{array}$ & EA crítica \\
\hline $\begin{array}{l}\text { Ciências da } \\
\text { Natureza }\end{array}$ & $\begin{array}{l}\text { "Utilização dos espaços da escola, seu entorno e da } \\
\text { cidade para a aprendizagem e a produção de } \\
\text { conhecimento relacionado à ciência, a fim de fortalecer } \\
\text { as relações de pertencimento da comunidade [...]". }\end{array}$ & EA crítica \\
\hline Geografia & $\begin{array}{l}\text { "Apropriar-se de espaços, intervir e promover } \\
\text { mudanças sobre os pontos e localidades importantes } \\
\text { do município" }\end{array}$ & EA crítica \\
\hline História & $\begin{array}{l}\text { "O conhecimento histórico torna-se instrumento de } \\
\text { investigação da realidade [...]. Logo, passa a ser um } \\
\text { meio para resolução de problemas e transformação } \\
\text { social [...]". }\end{array}$ & EA crítica \\
\hline Arte & $\begin{array}{l}\text { "Inter-relacionar tradição e contemporaneidade } \\
\text { entendendo a arte como práxis social. Experimentar e } \\
\text { compreender a arte em seus aspectos do fazer [...], do } \\
\text { ler [...] e do contextualizar (relações sociopolítico- } \\
\text { culturais historicamente construídas)." }\end{array}$ & EA crítica \\
\hline Educação Física & $\begin{array}{l}\text { "Compreender as relações de poder presentes na } \\
\text { produção de identidades estereotipadas atreladas às } \\
\text { manifestações da cultura corporal". }\end{array}$ & EA crítica \\
\hline $\begin{array}{l}\text { Direitos de } \\
\text { Aprendizagem do } \\
\text { Ciclo } \\
\text { Interdisciplinar e } \\
\text { Autoral }\end{array}$ & $\begin{array}{l}\text { "Processos contínuos e permanentes de formação, } \\
\text { individual e coletiva, que utilizem metodologias } \\
\text { participativas e interdisciplinares para a ação reflexiva } \\
\text { e crítica, a construção de valores e saberes, visando } \\
\text { ao exercício da cidadania na melhoria da qualidade de } \\
\text { vida, no controle social sobre as políticas públicas." }\end{array}$ & EA crítica \\
\hline
\end{tabular}

Fonte: (SÃO PAULO, 2016a, 2016b, 2016c, 2016d, 2016e, 2016f, 2016g, 2016h, 2016i). 
No ano de 2017, iniciou-se a nova gestão no município de São Paulo com uma outra proposta curricular, o Currículo da Cidade que foi elaborado com base na Base Nacional Comum Curricular (BNCC). No momento da construção deste documento, a BNCC não havia sido aprovada nem reformulada. Somente em 15 de dezembro de 2018 foi revalidada em todo o território nacional pelo Conselho Nacional de Educação, trazendo as novas diretrizes para orientar a elaboração dos currículos (BRASIL, 2018a).

O Currículo da Cidade a partir do ano de 2017 representa a política pública educacional da PMSP e norteia o currículo para o ensino fundamental (SÃO PAULO, 2017a). Nesse documento encontram-se algumas particularidades do currículo da gestão anterior, nos anos de 2013 a 2016, ratificando os direitos de aprendizagem e o TCA, com a intervenção social e resolução de problemas, quesitos que apontam para uma EA crítica.

Entretanto, a concepção de EA se mostra em outra concepção nos cadernos das disciplinas do Currículo da Cidade, São Paulo, (2017a): Arte, São Paulo (2017b); Educação Física, São Paulo (2017c); Geografia, São Paulo (2017d); História, São Paulo (2017e); Língua Inglesa, São Paulo (2017f); Língua Portuguesa, São Paulo (2017g); Tecnologia de Aprendizagem, São Paulo (2017h) e Matemática, São Paulo (2017i) (Quadro 6).

Quadro 6: Concepção de EA presentes no Currículo da Cidade baseado na BNCC (LAYRARGUES; LIMA, 2014).

\begin{tabular}{|c|c|c|}
\hline DISCIPLINAS & EDUCAÇÃO AMBIENTAL & CONCEPÇÃO DE EA \\
\hline $\begin{array}{c}\text { Língua } \\
\text { Portuguesa }\end{array}$ & Nada Consta & - \\
\hline Língua Inglesa & Nada Consta & - \\
\hline Matemática & $\begin{array}{l}\text { "Desenvolver um projeto explorando a conservação } \\
\text { dos oceanos, mares e recursos marítimos para o } \\
\text { desenvolvimento sustentável, relacionando-o com a } \\
\text { Matemática." }\end{array}$ & $\begin{array}{c}\text { EA } \\
\text { conservacionista }\end{array}$ \\
\hline $\begin{array}{l}\text { Ciências da } \\
\text { Natureza }\end{array}$ & $\begin{array}{l}\text { "Compreender como a tecnologia está relacionada } \\
\text { à produção e consumo dos recursos naturais, } \\
\text { afetando o meio ambiente." }\end{array}$ & EA pragmática \\
\hline Geografia & $\begin{array}{l}\text { "Ler imagens, identificando a presença da natureza } \\
\text { e das ações humanas em seu cotidiano e } \\
\text { reconhecer aspectos naturais do meio ambiente do } \\
\text { local de moradia." }\end{array}$ & $\begin{array}{c}\text { EA } \\
\text { conservacionista }\end{array}$ \\
\hline História & Nada Consta & - \\
\hline Arte & Nada Consta & - \\
\hline Educação Física & Nada Consta & - \\
\hline $\begin{array}{l}\text { Tecnologia de } \\
\text { aprendizagem }\end{array}$ & Nada Consta & - \\
\hline
\end{tabular}

Fonte: SÃO PAULO, 2017a, 2017b, 2017c, 2017d, 2017e, 2017f, 2017g, 2017h, 2017i. 
Ao longo das diversas páginas referentes às disciplinas do Currículo da Cidade, não se encontram as palavras Educação Ambiental ou qualquer menção direta a ela, com exceção da disciplina de matemática, na qual o tema aparece uma única vez, sugerindo que se realize um projeto de conservação de mares e oceanos, apontando uma EA conservacionista (LAYRARGUES; LIMA, 2014; SÃO PAULO, 2017i).

$\mathrm{Na}$ disciplina de Ciências sugere-se a compreensão da tecnologia em relação aos consumos dos recursos naturais, trazendo indícios de uma EA pragmática, por propor 0 desenvolvimento sustentável e a revolução tecnológica como alternativas à crise ambiental (LAYRARGUES; LIMA, 2014; SÃO PAULO, 2017a).

$\mathrm{Na}$ disciplina de Geografia, nos diversos objetivos de aprendizagem e desenvolvimento, há sugestões para que o docente elabore atividades aos estudantes, apontando uma EA conservacionista e pragmática. Entretanto, as orientações gerais sobre o saber geográfico indicam uma EA crítica, quando se afirma que o processo de "regionalização desconstrói um mundo organizado por um conjunto de variáveis estáticas e aborda como as relações e interações ocorrem nos campos econômicos, políticos, meio ambiente entre outros" (SÃO PAULO, 2017d p. 79).

Nas demais disciplinas - Língua Portuguesa, Língua Inglesa, História, Arte e Educação Física - não se observou qualquer menção a EA no Currículo da Cidade, semelhante ao que ocorre na Base Nacional Comum Curricular (SÃO PAULO, 2017).

Mesmo sendo um produto inacabado, não linear e plural, por envolver diversos saberes e culturas, o currículo é um orientador para o Projeto Político Pedagógico e planos de ensino. Por isso, é importante que a Educação Ambiental, com suas concepções e práticas, sejam referenciadas em um documento deste porte, reafirmando as políticas públicas ambientais e solidificando-se como política pública educacional para nortear ações pedagógicas de um município (SÃO PAULO, 2017a, 2017b, 2017c, 2017d, 2017e, 2017f, 2017g, 2017h, 2017i.).

O Currículo da Cidade incorporou os Objetivos de Desenvolvimento Sustentável (ODS) pactuados na Agenda 2030, que traz um discurso sobre garantir e assegurar aos seres humanos um ambiente saudável, a proteção ao planeta da degradação ambiental, a promoção da paz e a parceria para atingir o Desenvolvimento Sustentável.

Evidentemente, todos os cidadãos devem contribuir para um desenvolvimento sustentável, mas a questão deve ir além da responsabilização individual: há uma necessidade e urgência em debater sobre "como atingir o ODS" na esfera escolar. Como atingir tantos objetivos sustentáveis com o desenvolvimento econômico atual? Como cumprir as ODS até 2030 sem dar a devida atenção à EA? Como garantir um ambiente saudável deixando de lado 
o debate da justiça ambiental, a inclusão social e a democracia, que são alguns dos pilares que preconizam a EA crítica?

Um ambiente ideal está nos sonhos de toda a humanidade. Desse modo, as escolas necessitam realizar práticas que estimulem transformações na sociedade e, para isso, o docente deve se perceber como educador ambiental e executar trabalhos que estimulem a percepção ambiental do estudante. Se não for o docente a desenvolver esse papel na educação básica, quem será?

O POP, projeto interdisciplinar de intervenção social, surgiu de uma demanda da política pública educacional "Mais Educação São Paulo". Esse projeto propiciou a todos os atores envolvidos um olhar para uma praça com seus problemas, em busca de soluções. A busca por soluções de problemas ambientais contemporâneos é um dos objetivos a serem atingidos pela área de Ciências Ambientais. Este projeto ressignificou 0 espaço público, proporcionando o envolvimento da comunidade escolar e da comunidade de seu entorno, trazendo-Ihes pertencimento e topofilia. O estímulo de uma atuação individual e coletiva quanto aos cuidados com o meio ambiente, somado à criação de uma cultura de participação democrática que una o indivíduo e a sociedade em um movimento dialógico e que também questione o poder público quanto a sua participação na preservação do espaço público, demonstram que o POP está comprometido com uma Educação Ambiental Crítica. Este projeto reforça a importância de se elaborar políticas públicas educacionais que favoreçam as práticas ambientais coletivas.

A aparente visão globalizante dos docentes e discentes sobre o meio ambiente, juntamente com a concepção de EA dos docentes, trazem indícios de que o POP impactou essa comunidade escolar. A maioria dos respondentes atuou de forma efetiva no projeto e, em seus desenhos, os símbolos indicaram a complexa relação existente entre o homem e seu entorno. Estes símbolos apontam ainda a interferência humana na natureza. A maioria dos docentes e discentes não demonstrou uma visão naturalista. Não percebem o meio ambiente como uma natureza intocada e nem se vêem apartados dela, pois em seus desenhos, geralmente, registram a presença humana ou objetos confeccionados por eles.

Os registros do POP foram encontrados no currículo da escola, PPP e PEA, desde a sua construção, elaboração e resultados, indicando o quão importante é a construção coletiva desses documentos, partindo das necessidades de uma comunidade. Concluiu-se, então, que no currículo do município de São Paulo, as Orientações Curriculares do ano de 2012, demonstravam uma concepção de EA conservacionista. Entre 2013 e 2016 o projeto Mais Educação São Paulo, representado pelos Direitos de Aprendizagem, trouxe uma concepção de EA crítica. E, finalmente, o Currículo da Cidade elaborado no ano de 2017, de acordo com a Base Nacional Comum Curricular, não oferece nenhum indicativo de concepção em EA. 


\section{Considerações Finais}

A EA está prevista em políticas públicas ambientais como: legislações federais, estaduais e municipais. Também há indicativos para o seu desenvolvimento em algumas políticas públicas educacionais. Entretanto, não está presente no atual currículo do município de São Paulo, representado pelo Currículo da Cidade.

Para contemplá-la, a comunidade escolar deverá inserir debates e práticas interdisciplinares com uma concepção de EA vinculada ao Projeto Político-Pedagógico e ao Plano Especial de Ação. Desse modo, ficará registrada e estabelecida sua execução, dando grande possibilidade de se abranger um maior número de docentes e discentes.

O Currículo da Cidade, fundamentado a partir da Base Nacional Comum Curricular, é obrigatório para todas as unidades escolares do município de São Paulo. Para que se estabeleçam currículos próprios das escolas, pautados no Currículo da Cidade, é necessário oferecer formação continuada aos profissionais de educação. Mesmo com a formação de todos estes profissionais fica a seguinte pergunta: será que o Currículo da Cidade é suficiente para atender as necessidades das escolas do município de São Paulo? A Educação Ambiental não deveria ser considerada neste documento?

O impacto da política pública "Mais Educação São Paulo" permitiu a execução de um Trabalho Colaborativo de Autoria com participação social em Educação Ambiental Crítica. Por sua vez, o Currículo da Cidade do Município de São Paulo está indo para o seu terceiro ano com uma nova visão curricular que não contempla, discute ou propõe ações interdisciplinares em Educação Ambiental. Qual será seu impacto futuro nesta área?

Nesse sentido, a escola deverá buscar reflexões entre a teoria e a prática, debatendo qual concepção de meio ambiente e de EA almeja atingir. Este pode ser um caminho para uma transformação positiva da sociedade em relação ao meio ambiente.

\section{Referências}

ALMEIDA L.F.R.; BICUDO, L.R.H.; BORGES, G.L.A Educação ambiental em praças públicas: professores e alunos descobrindo 0 ambiente urbano. Rev.Ciênc. Ext., v.1, n.1, p. 92, 2004.

BAEDER A.M. et al. Jovens em ação! Ações para melhorar o ambiente e a qualidade de vida nas cidades. São Paulo: Companhia Melhoramentos, 2000.

BARDIN, L. Análise de Conteúdo. Lisboa: Edições 70, 1977.

BRASIL. Lei n. 9.795, de 27 de abril de 1999. Dispõe sobre a Educação Ambiental, institui a Política Nacional de Educação Ambiental e dá outras providências, 1999. 
BRASIL. Ministério da Educação. Secretaria da Educação Básica. Diretrizes curriculares nacionais gerais da educação básica. Brasília: MEC/SEB/DICEI, 2013.

BRASIL. Ministério da Educação. Base Nacional Comum Curricular. Brasília: MEC, 2018a. Disponível em: <http://basenacionalcomum.mec.gov.br/wp-con tent/uploads/2018a/12/BNCC 19dez2018 site.pdf/ $\geq$. Acesso em: 1 set. 2018.

CALDEIRA, J.M. A praça brasileira: trajetória de um espaço urbano: origem e modernidade. 2007. Tese (Doutorado em História) - Instituto de Filosofia e Ciências Humanas, Universidade Estadual de Campinas, Campinas, SP, 2007.

CARMO, H.M.A.; MOURA, W.K.A.; SOUZA, P.D.F.B. Representações gráficas sobre meio ambiente de alunos da escola Est. Prof. Luiz Antônio (Natal/RN). Revista Educação Ambiental em Ação, a. 12, n. 45, set.-nov. 2013.

CRESWELL JOHN, W. Projeto de pesquisa: métodos qualitativo, quantitativo e misto. 2. ed. Porto Alegre: Artmed, 248 p, 2010.

DALL'ONDER, A. Educação ambiental e resíduos sólidos: um estudo nas escolas públicas municipais de São Paulo. 2018. Dissertação (Mestrado em Sustentabilidade) - Escola de Artes, Ciências e Humanidades, Universidade de São Paulo, São Paulo, 2018. Disponível em: <http://www.teses.usp.br/teses/ disponiveis/100/100136/tde-09042018-095938/>. Acesso em: 12 jun. 2018.

FARIAS L.A. et al. Opposite shores: a case study of environmental perception and social representations of public school teachers in Brazil. International Research in Geographical and Environmental Education, v. 27, iss. 1, p. 43-55, fev. 2017.

FERRARA L.D.A. Olhar periférico: informação. linguagem, percepção ambiental. São Paulo: 2 ed. Editora da Universidade de São Paulo, 1999.

FREIRE, P. Pedagogia do oprimido: saberes necessários a práticas educativas. São Paulo: Paz e Terra, 1987.

FREIRE, P. Pedagogia da Autonomia. São Paulo: Paz e Terra, 1996.

INSTITUTO BRASILEIRO DE GEOGRAFIA E ESTATÍSTICA. IBGE Censo Demográfico. 2010. Disponível em: <https://censo2010.ibge.gov.br/>. Acesso em: 22 jun. 2018.

LAYRARGUES, P.P.; LIMA, G.F.C. Mapeando as macrotendências políticopedagógicas da educação ambiental contemporânea no Brasil. Ambiente \& Sociedade, São Paulo, v. 17, n. 1, p. 23-40, 2014.

LEITE. J.K.S. et al. Envolvimento Sustentável: o UFPE na praça incentivando a educação ambiental. Revista Brasileira de Educação Ambiental, São Paulo, v. 10, n. 1, p. 301-315, 2015.

LEFF, E. Complexidade, interdisciplinaridade e saber ambiental. In: PHILIPPI Jr. A. et al. Interdisciplinaridade em ciências ambientais. São Paulo: Signus, p. $179,2000$. 
MARTINS, G.A. Estudo de caso: uma estratégia de pesquisa. 2. ed. São Paulo: Atlas, 2008. $120 \mathrm{p}$.

MAZZON, J.A. Análise do programa de alimentação do trabalhador sob o conceito de marketing social. Tese de Doutorado - Faculdade de Economia, Administração e Contabilidade da Universidade de São Paulo, São Paulo. 1981

MOREIRA, A.F.B. Currículo: Conhecimento e Cultura sobre a qualidade na educação básica. Ministério da Cultura, Ano XIX, n. 1, 2009.

MOSCOVICl, S. A representação social da psicanálise. Trad. de Álvaro Cabral. Rio de Janeiro: Zahar, 291 p, 1978.

OLABUENAGA, J.I.R.; ISPIZUA, M.A. La descodificación de la vida cotidiana: metodos de investigacion cualitativa. Bilbao: Universidad de Deusto, 1989.

OTERO, P.B.G.; NEIMAN, Z. Avanços e desafios da educação ambiental brasileira entre a Rio 92 e a Rio+20. Revista Brasileira de Educação Ambiental, v. 10, p. 20-41, 2015.

PACHECO, J.A. Teorias curriculares: políticas, lógicas e processos de regulação regional das práticas curriculares. Conferência realizada no âmbito do Seminário "O Currículo Regional", Terceira, Açores. Vol. 4. 2003.

PEDRINI, A.G.; COSTA, E.; GHILARDI, N. Percepção ambiental de crianças e pré-adolescentes em vulnerabilidade social para projetos de educação. Ciência \& Educação, v. 16, n. 1, p. 163-179, 2010.

PHILIPPI JUNIOR., A. et al. Interdisciplinaridade em Ciências Ambientais. São Paulo: Signus, p. 179, 2000.

REIGOTA, M. Meio ambiente e representação social. 7. ed. São Paulo: Cortez, Coleção Questões de Nossa Epoca, 2007.

REIGOTA, M. Educação Ambiental: a emergência de um campo científico. Perspectivas, Florianópolis, v. 30, n. 2, pp. 499-520, maio/ago. 2012.

REIGOTA, M. O que é educação ambiental. São Paulo: Brasiliense, 2017.

RIBEIRO, W.C.; LOBATO, W.; LIBERATO, R.C. As percepções dos docentes do curso de ciências biológicas do uni-BH sobre meio ambiente e educação ambiental. Revista Sinapse Ambiental, v. 7, n. 1, set. 2010.

SAITO, C.H. Popularizando o Probio: educação ambiental na praça e na escola. Revista Brasileira Educação Ambiental, Rio Grande, v. 7, n. 2, pp. 83-95, 2012.

SÃO PAULO (Município). Orientações Curriculares do Município de São Paulo. 2007a. Disponível em: <http://www.cdcc.usp.br/cda/PARAMETROSCURRICULARES/Portal-Secretaria-Municipal-De-Educacao-Sao-PauloCapital/EF-CICLOII/OrientacpesCurriculares proposicao expectativas de aprendizagem EnsFundll Cie.pdf>. Acesso em: 17 fev. 2018. 
SÃO PAULO (Município). Secretaria do Trabalho, Desenvolvimento e Empreendendorismo da Cidade de São Paulo. Atlas Municipal. 2007b. Disponível em: <http://atlasmunicipal.prefeitura.sp.gov.br/Download/frm Download.aspx>. Acesso em: 10 mar. 2018.

SÃO PAULO (Municí́io). Lei no 14660, de 26 dez. 2007. Dispõe sobre o Estatuto dos Profissionais da Educação Municipal. 2007c. Disponível em: $<$ http://www3.prefeitura.sp.gov.br/cadlem/secretarias/negocios juridicos/cadlem lintegra.asp?alt=27122007L\%20146600000 >. Acesso em: 3 dez. 2016.

SÃO PAULO (Município). Programa Mais Educação São Paulo - Subsídios para a implantação. 2014a. Disponível em: <http://portal.sme.prefeitura. sp.gov.br/programa-maiseducacao-sao-paulo-1> . Acesso em: 16 jan. 2018.

SÃO PAULO (Município). Portaria 901, de 2014. Dispõe sobre Projetos Especiais de Ação -PEAs e dá outras providências. 2014b. Disponível em: $<$ http://legislacao.prefeitura.sp.gov.br/leis/portaria-secretaria-municipal-da-edu cacao-901-de-25-de-janeiro-de-2014/consolidado>. Acesso em: 1 mar. 2019.

SÃO PAULO (Município). Programa mais educação São Paulo - Plano de navegador - Aluno. 2014c Disponível em: <http://portal.sme.prefeitura.sp. gov.br/programa-mais-educacao-sao-paulo-1> . Acesso em: 16 jan. 2018.

SÃO PAULO (Município). Secretaria da Educação. Plano de Navegação do Autor: professor. 2014d. Disponível em:<http://portal.sme.prefeitura.sp.gov.br/ Main/Noticia/Visualizar/PortalSMESP/Planos-de-Navegacao-AutorAluno-eAutorProfessor>. Acesso em: 3 set. 2018.

SÃO PAULO (Município). Secretaria Municipal de Educação. Direitos de Aprendizagem dos Ciclos Interdisciplinar e Autoral. Coleção Componentes Curriculares em Diálogos Interdisciplinares a Caminho da Autoria. 72 p. 2016a.

SÃO PAULO (Município). Secretaria Municipal de Educação. Direitos de Aprendizagem dos Ciclos Interdisciplinar e Autoral. Coleção Componentes Curriculares em Diálogos Interdisciplinares a Caminho da Autoria. Ciências Naturais. 81 p. 2016b. Disponível em: <http://portal.sme.prefeitura.sp.gov.br/ Colecao-Componentes-Curriculares $>$. Acesso em: 15 out. 2017.

SÃO PAULO (Município). Secretaria Municipal de Educação. Direitos de Aprendizagem dos Ciclos Interdisciplinar e Autoral. Coleção Componentes Curriculares em Diálogos Interdisciplinares a Caminho da Autoria. Língua Portuguesa. 100 p. 2016c Disponível em: <http://portal.sme.prefeitura. sp.gov.br/ Portals/1/Files/40768.pdf>. Acesso em: 15 out. 2017.

SÃO PAULO (Município). Secretaria Municipal de Educação. Direitos de Aprendizagem dos Ciclos Interdisciplinar e Autoral. Coleção Componentes Curriculares em Diálogos Interdisciplinares a Caminho da Autoria. Língua Inglesa. 76 p. 2016d. Disponível em: <http://portal.sme.prefeitura.sp.gov.br/ Portals/1/Files/40771.pdf> . Acesso em: 15 out. 2017. 
SÃO PAULO (Município). Secretaria Municipal de Educação. Direitos de Aprendizagem dos Ciclos Interdisciplinar e Autoral. Coleção Componentes Curriculares em Diálogos Interdisciplinares a Caminho da Autoria. História. 108 p. 2016e. Disponível em:<http://portal.sme.prefeitura.sp.gov.br/Portals/ 1/Files/40774.pdf > . Acesso em: 15 out. 2017.

SÃO PAULO (Município). Secretaria Municipal de Educação. Direitos de Aprendizagem dos Ciclos Interdisciplinar e Autoral. Coleção Componentes Curriculares em Diálogos Interdisciplinares a Caminho da Autoria. Matemática. 116 p. 2016f. Disponível em:<http://portal.sme.prefeitura.sp.gov.br/Portals/1/ Files/40772.pdf>. Acesso em: 15 out. 2017.

SÃO PAULO (Município). Secretaria Municipal de Educação. Direitos de Aprendizagem dos Ciclos Interdisciplinar e Autoral. Coleção Componentes Curriculares em Diálogos Interdisciplinares a Caminho da Autoria. Geografia. 84 p. 2016g. Disponível em: <http://portal.sme.prefeitura.sp.gov.br/Portals/1/ Files/40783.pdf>. Acesso em: 15 out. 2017.

SÃO PAULO (Município). Secretaria Municipal de Educação. Direitos de Aprendizagem dos Ciclos Interdisciplinar e Autoral. Coleção Componentes Curriculares em Diálogos Interdisciplinares a Caminho da Autoria. Arte. 116 p. 2016h. Disponível em:<http://portal.sme.prefeitura.sp.gov.br/Portals/1/ Files/40 784.pdf> . Acesso em: 15 out. 2017.

SÃO PAULO (Município). Secretaria Municipal de Educação. Direitos de Aprendizagem dos Ciclos Interdisciplinar e Autoral. Coleção Componentes Curriculares em Diálogos Interdisciplinares a Caminho da Autoria. Educação Física. 84 p. . 2016i. Disponível em: <http://portal.sme.prefeitura.sp.gov.br/ Portals/1/Files/40775.pdf> . Acesso em: 15 out. 2017.

SÃO PAULO (Município). Currículo da Cidade: Ciências. São Paulo: Município de São Paulo, 2017a. Disponível em: <http://portal.sme.prefeitura. sp.gov.br/Portals/1/ Files/47274.pdf> Acesso em: 3 set. 2018.

SÃO PAULO (Município). Currículo da Cidade: Arte. São Paulo: Município de São Paulo, 2017b. Disponível em:<http://portal.sme.prefeitura.sp.gov.br /Portals/1/Files/ 47270.pdf> Acesso em: 02 set. 2018.

SÃO PAULO (Município). Currículo da Cidade. Educação Física. São Paulo: Município de São Paulo, 2017c. Disponível em: <http://portal.sme.prefeitura. sp.gov.br/Portals/ 1/ Files/47276.pdf>. Acesso em: 02 set. 2018.

SÃO PAULO (Município). Currículo da Cidade. Geografia. São Paulo: : Município de São Paulo, 2017d. Disponível em: <http://portal.sme.prefeitura. sp.gov.br/Portals/1/Files/47273.pdf>. Acesso em: 03 set. 2018.

SÃO PAULO (Município). Currículo da Cidade. História. São Paulo: : Município de São Paulo, 2017e. Disponível em: <http://portal.sme.prefeitura. sp.gov.br/Portals/1/Files/48331.pdf>. Acesso em: 01 set. 2018. 
SÃO PAULO (Município). Currículo da Cidade. Língua Inglesa. São Paulo: : Município de São Paulo, 2017f. Disponível em: <http://portal.sme.prefeitura. sp.gov.br/Portals/1/Files/47277.pdf>. Acesso em: 01 set. 2018.

SÃO PAULO (Município). Currículo da Cidade. Língua Portuguesa. São Paulo: Município de São Paulo, 2017g Disponível em: <http://portal.sme. prefeitura.sp.gov.br/Portals/1/Files/47271.pdf>. Acesso em: 01 set. 2018.

SÃO PAULO (Município). Currículo da Cidade. Tecnologia de Aprendizagem. São Paulo: : Município de São Paulo,, 2017h. Disponível em: $<$ http://portal.sme.prefeitura.sp.gov.br/Portals/1/Files/47275.pdf> Acesso em: 03 set. 2018.

SÃO PAULO (Município). Currículo da Cidade. Matemática. São Paulo: : Município de São Paulo, 2017i. Disponível em: <http://portal.sme.prefeitura. sp.gov.br/Portals/1/Files/47272.pdf> . Acesso em: 01 set. 2018.

SANTANA A.S. Percepção ambiental e representação social de jovens estudantes do município de Santos na região costeira de São Paulo: um estudo de caso sobre trilhas urbanas ambientais. 2108. Dissertação (Mestrado em Ciências Ambientais, Análise Ambiental Integrada) - Instituto de Ciências Ambientais, Químicas e Farmacêuticas da Universidade Federal de São Paulo - Campus Diadema, 2018.

SILVA, E.A. A cartografia municipal. A mira agrimensura e cartografia. Seção Técnica Cartografia, ano XIX-152, Rio de Janeiro, 2009.

STAKE, R.E. Pesquisa Qualitativa: estudando como as coisas funcionam. São Paulo: Penso, 263 p, 2011.

SANTANA, A.; ROMERO, F.C.; FARIAS, L.A. Trilhas urbanas e o seu papel na percepção ambiental e ressignificação da representação social de meio ambiente: um estudo de caso em uma escola pública brasileira. 2019. Educação Ambiental em Ação, São Paulo, n. 67, ano XVII, marçomaio/2019.

TREVISOL, J.V. Os professores e a educação ambiental: um estudo de representações sociais em docentes das Séries Iniciais do Ensino Fundamental. Anais do II Encontro da Associação Nacional de Pós-Graduação e Pesquisa em Ambiente e Sociedade, p. 01-20, 2004.

TUAN, Y.F. Topofilia: um estudo da percepção, atitudes e valores do meio ambiente. Trad. de Lívia de Oliveira. Londrina: EdUEL, 2012.

VEIGA, I.P.A. Projeto político-pedagógico da escola: uma construção possível. 14. ed. São Paulo: Papirus, 2002.

YIN, R. Estudo de Caso: planejamento e métodos. São Paulo: Bookman, 290 p. 2010. 